Published in final edited form as:

Pain. 2016 March ; 157(3): 613-626. doi:10.1097/j.pain.0000000000000410.

\title{
The $a_{5}$ subunit-containing $\mathrm{GABA}_{\mathrm{A}}$ receptors contribute to chronic pain
}

\author{
Mariana Bravo-Hernández ${ }^{a}$, José A. Corleto ${ }^{b}$, Paulino Barragán-Iglesias ${ }^{a}$, Ricardo \\ González-Ramírez ${ }^{\mathrm{c}, \mathrm{d}}$, Jorge B. Pineda-Farias ${ }^{\mathrm{a}}$, Ricardo Felix ${ }^{\mathrm{c}}$, Nigel A. Calcutt ${ }^{\mathrm{e}}$, Rodolfo \\ Delgado-Lezama $^{f}$, Martin Marsalab,g, and Vinicio Granados-Soto ${ }^{a}{ }^{*}$ \\ aNeurobiology of Pain Laboratory, Departamento de Farmacobiología, Centro de Investigación y \\ de Estudios Avanzados, Sede Sur. Calzada de los Tenorios 235, Col. Granjas Coapa, Tlalpan, \\ 14330 México, D.F., MEXICO \\ bNeuroregeneration Laboratory, Department of Anesthesiology, University of California San \\ Diego, La Jolla, CA, 92093, USA \\ 'Departamento de Biología Celular, Centro de Investigación y de Estudios Avanzados. Av. \\ Instituto Politécnico Nacional 2508, San Pedro Zacatenco, Gustavo A. Madero, 07360 México, \\ D.F., MEXICO \\ dDepartamento de Biología Molecular e Histocompatibilidad, Hospital General "Dr. Manuel Gea \\ González". Av. Calzada de Tlalpan 4800, Tlalpan, Sección XVI, 14080, México, D.F., MEXICO \\ eDepartment of Pathology, University of California San Diego, La Jolla, CA, 92093, USA \\ fDepartamento de Fisiología, Biofísica y Neurociencias, Centro de Investigación y de Estudios \\ Avanzados. Av. Instituto Politécnico Nacional 2508, San Pedro Zacatenco, Gustavo A. Madero, \\ 07360 México, D.F., MEXICO \\ Institute of Neurobiology, Soltesovej 4, 04001 Kosice, Slovakia
}

\section{Abstract}

It has been recently proposed that $\alpha_{5}$-subunit containing $\mathrm{GABA}_{\mathrm{A}}$ receptors $\left(\mathrm{a}_{5}-\mathrm{GABA}_{\mathrm{A}}\right.$ receptors $)$ that mediate tonic inhibition might be involved in pain. The purpose of this study was to investigate the contribution of $\mathrm{a}_{5}-\mathrm{GABA}_{\mathrm{A}}$ receptors in the loss of GABAergic inhibition and in formalin-, Complete Freund's adjuvant (CFA)- and L5/L6 spinal nerve ligation-induced longlasting hypersensitivity. Formalin or CFA injection and L5/L6 spinal nerve ligation produced longlasting allodynia and hyperalgesia. Moreover, formalin injection impaired the rate-dependent depression (RDD) of the Hofmann reflex. Peripheral and intrathecal pre-treatment or posttreatment with the $a_{5}-\mathrm{GABA}_{\mathrm{A}}$ receptor antagonist, L-655,708 (0.15-15 nmol) prevented and reversed, respectively, these long-lasting behaviors. Formalin injection increased $a_{5}-G_{B B A}$ receptors mRNA expression in the spinal cord and dorsal root ganglia (DRG) mainly at 3 days. $\mathrm{a}_{5^{-}}$

*Corresponding author at: Vinicio Granados-Soto, Ph.D., Departamento de Farmacobiología, Cinvestav, Sede Sur, Calzada de los Tenorios 235, Colonia Granjas Coapa, C.P. 14330, México, D.F., México, Tel.: +52 555483 2868, Fax: +52 5554832863 , vgranados@ prodigy.net.mx, vgranados@ cinvestav.mx.

Conflict of interest

The authors declare no competing financial interests. 
$\mathrm{GABA}_{\mathrm{A}}$ receptors were localized in the dorsal spinal cord and DRG co-labeling with NeuN, CGRP and IB4 suggesting their presence in peptidergic and non-peptidergic neurons. These receptors were found mainly in small- and medium-size neurons. Formalin injection enhanced $\mathrm{a}_{5}$ $\mathrm{GABA}_{\mathrm{A}}$ receptors fluorescence intensity in spinal cord and DRG at 3 and 6 days. Intrathecal administration of L-655,708 (15 nmol) prevented and reversed formalin-induced impairment of $\mathrm{RDD}$. These results suggest that $\mathrm{a}_{5}-\mathrm{GABA}_{\mathrm{A}}$ receptors play a role in the loss of GABAergic inhibition and contribute to long-lasting secondary allodynia and hyperalgesia.

\section{Keywords}

Chronic pain; $\mathrm{GABA}_{\mathrm{A}}$ receptors; $\mathrm{a}_{5}$ subunit-containing $\mathrm{GABA}_{\mathrm{A}}$ receptors; secondary allodynia; secondary hyperalgesia; RDD; loss of inhibition

\section{Introduction}

The role of $\mathrm{GABA}_{\mathrm{A}}$ receptors in chronic pain is a matter of debate. Activation of neuronal $\gamma-$ amino butyric acid (GABA) receptors leads to hyperpolarization, and thus GABA is considered the main inhibitory neurotransmitter in the mature central nervous system. Interestingly, $\mathrm{GABA}_{\mathrm{A}}$ receptors activation also leads to depolarization [38,61]. Under normal conditions, $\mathrm{GABA}_{\mathrm{A}}$ receptor agonists produce antinociception while antagonists elicit pronociception $[5,65,72]$. However, tissue or nerve injury appears to switch $\mathrm{GABA}_{\mathrm{A}}$ receptors function with $\mathrm{GABA}_{\mathrm{A}}$ receptors agonists promoting nociception whereas antagonists produce antinociception $[3,19,55]$. This switch has been attributed to a loss of $\mathrm{GABA}_{\mathrm{A}}$ receptors-mediated spinal inhibition (central disinhibition). The loss in inhibition has been explained by a depolarizing shift of GABA reversal potential $\left(\mathrm{E}_{\mathrm{GABA}}\right)$ produced by an increased expression of the $\mathrm{Na}^{+}-\mathrm{K}^{+}-2 \mathrm{Cl}^{-}$co-transporter 1 (NKCC1) and/or reduced expression of $\mathrm{K}^{+}-\mathrm{Cl}^{-}$co-transporter $2(\mathrm{KCC} 2)$ or by the participation of extrasynaptic $\mathrm{GABA}_{\mathrm{A}}$ receptors $[56,70,73]$.

$\mathrm{GABA}_{\mathrm{A}}$ receptors are heteropentameric ligand-gated chloride channels [51]. To date, several subunits have been cloned including $a(1-6), \beta(1-3), \gamma(1-3), \delta, \varepsilon, \theta, \pi$ and $\rho(1-3)$ [25]. The $\mathrm{GABA}_{\mathrm{A}}$ receptors mediate both phasic and tonic inhibition. The subunit composition of the $\mathrm{GABA}_{\mathrm{A}}$ receptors determines whether the receptors are more likely to participate in the generation of transient post-synaptic or pre-synaptic inhibition or a form of tonic inhibition [25]. Tonic inhibition is generated by extrasynaptic $a_{5}$ subunit-containing $\mathrm{GABA}_{\mathrm{A}}$ receptors $\left(a_{5}-G_{A B A}\right.$ receptors), among others, in the brain $[7,25,32,62,63]$ and particularly in the spinal cord $[14,21,41]$. It has been demonstrated that tonically active $a_{5}-\mathrm{GABA}_{\mathrm{A}}$ receptors modulate dorsal root reflexes by affecting excitability via tonic depolarization, suggesting that they might play an important role in pain $[21,41,62]$. Consistent with this hypothesis, we previously demonstrated that $\mathrm{a}_{5}-\mathrm{GABA}_{\mathrm{A}}$ receptor blockade leads to antinociception in the rat formalin test [11]. Notably, $a_{5}-\mathrm{GABA}_{\mathrm{A}}$ receptors have been localized at the dorsal horn in mice and rats $[43,53]$ and are also found in DRG and peripheral nerve fibers in turtles [41], making them well placed to modulate the nociceptive process. However, the role of $a_{5}-\mathrm{GABA}_{\mathrm{A}}$ receptors in chronic inflammatory or neuropathic pain is unclear. Here we used formalin-, Complete Freund's adjuvant (CFA)- and spinal nerve ligation-induced long- 
lasting hypersensitivity to assess the possible involvement of $a_{5}-\mathrm{GABA}_{\mathrm{A}}$ receptors in central disinhibition and chronic pain.

\section{Materials and Methods}

\section{Animals}

These experiments were carried out in female Wistar rats. We did not find significant differences between formalin- and CFA- (unpublished data) or spinal nerve injury [12]induced responses between male and female rats. For the evaluation of formalin- and CFAinduced long-lasting hypersensitivity, rats at 8-10 weeks of age (body weight 180-200 g) were used. In the case of the L5/L6 spinal nerve ligation model, rats of 6 weeks (140-160 g) were used. Animals had free access to food and drinking water before the experiments. All experiments followed the Guidelines of Ethical Standards for Investigation of Experimental Pain in Animals [76] and were approved by our local Ethics Committee (Cinvestav, Mexico City) and by the Institutional Animal Care and Use Committees of the University of California, San Diego. Efforts were made to minimize the number of animals used.

\section{Induction and assessment of long-lasting secondary allodynia and hyperalgesia}

Rats were restrained gently in order to inject formalin $(0.5 \%$ or $1 \%)$ or Complete Freund's adjuvant (CFA) subcutaneously (s.c.) into the dorsal surface or the plantar surface on the right hind paw, respectively. Formalin-induced mechanical secondary allodynia and hyperalgesia starts 1 day after injection and lasts at least 12 days [1,15,28,30]. CFA-induced tactile allodynia starts at $6 \mathrm{~h} \mathrm{[44]} \mathrm{and} \mathrm{lasts} \mathrm{at} \mathrm{least} 18$ days [33]. Formalin-induced sensitization was assessed 3 and 6 days after injection $[1,2,44]$. CFA- or spinal nerve ligation-induced tactile allodynia was assessed at 3, 7 and 14 days later. At the end of the experiment, rats were sacrificed in a $\mathrm{CO}_{2}$ chamber.

In order to assess mechanical secondary allodynia and hyperalgesia or tactile allodynia, rats were placed into testing cages on a wire mesh bottom and allowed to acclimate for $30 \mathrm{~min}$. Baseline measurements were recorded by applying two von Frey filaments (Stoelting Co, Wood Dale, IL, USA, bending forces of $10 \mathrm{mN}[1 \mathrm{~g}]$ and $250 \mathrm{mN}$ [26 g]) to the base of the third toe on the plantar surface of both paws 10 times during each testing period to determine the response frequency for each filament. Three trials were completed to determine the paw response frequency [10,27]. A force of $10 \mathrm{mN}$ does not activate cutaneous nociceptors in naïve rats [40]; therefore, it does not lead to a paw withdrawal. Responses to the $10 \mathrm{mN}$ filament are therefore a clear indicator of the presence of secondary allodynia. On the other hand, a force of $250 \mathrm{mN}$ or more is considered a noxious stimulus [40] and hyperalgesia occurs when there is an increased response to these stimuli. Formalininduced allodynia and hyperalgesia were considered secondary, as stimuli with the von Frey filaments were applied in a site different from that of the formalin injection.

Assessment of tactile allodynia in spinal nerve ligated or CFA treated rats was carried out using a previously reported method [17]. 


\section{Intrathecal catheterization}

Spinal catheterization was performed 5 days before injection of formalin, CFA or L5/L6 spinal nerve ligation by using a previously reported method [42]. Briefly, rats were anesthetized with a ketamine/xylazine mixture ( $45: 12 \mathrm{mg} / \mathrm{kg}$, i.p.). Then, they were placed in a stereotaxic head holder, the atlanto-occipital membrane exposed and pierced in order to insert a polyethylene catheter (PE-10, 7.5-8 cm length) and moved towards the thoracolumbar region. Rats were housed and allowed to recover for 5 days before drug administration and testing.

\section{Drugs}

L-655,708 (ethyl(S)-11,12,13,13a-tetrahydro-7-methoxy-9-oxo-9H-imidazo[1,5a]pyrrolo[2,1-c][1,4]benzodiazepine-1-carboxylate) and CFA were purchased from SigmaAldrich (St. Louis, MO). L-838,417 (3-(2,5-difluorophenyl)-7-(1,1-dimethylethyl)-6-[(1methyl-1H-1,2,4-triazol-5-yl)methoxy]-1,2,4-triazolo[4,3-b]pyridazine) was purchased from Tocris Bioscience (Elisville, MO). All drugs were diluted in 20\% dimethyl sulfoxide (DMSO). Formaldehyde (37\%) was purchased from Merck Mexico, S.A. (Naucalpan, Mexico) and diluted in saline.

The drugs were chosen based on the availability, selectivity and efficacy as follows: i) L-655,708, a selective $\alpha_{5}-\mathrm{GABA}_{\mathrm{A}}$ receptors antagonist (pKi 9.3) [57] and ii) L-838,417, an $a_{2^{-}}, a_{3^{-}}$and $a_{5}-\mathrm{GABA}_{\mathrm{A}}$ receptors partial agonist with a pKi 8.6 for $\mathrm{a}_{5^{-}} \mathrm{GABA}_{\mathrm{A}}$ receptors [46].

\section{Quantitative reverse transcription PCR (RT-qPCR)}

Rats were sacrificed by decapitation, the dorsal spinal cord of the lumbar section was divided by a scalpel incision to enable the ipsilateral (injured) and contralateral (uninjured) sides to be identified. The ipsilateral L4-L6 DRGs were also excised. Total RNA was isolated with TRIzol reagent (Invitrogen, Carlsbad, CA). RNA was quantified by spectrophotometry using an absorbance of $260 \mathrm{~nm}$ (ThermoSpectronic, Genesys $10 \mathrm{UV}$, Madison, WI) and the sample purity ratios were calculated (260/280 nm). For cDNA synthesis, $5 \mu \mathrm{g}$ of total RNA was subjected to reverse transcription with random hexanucleotides and the M-MLV reverse transcriptase (Invitrogen, Carlsbad, CA), according to manufacturer's instructions. The qPCR were carried out using the TaqMan Universal PCR Master Mix in a total volume of $25 \mu \mathrm{l}$, containing $900 \mathrm{nM}$ of each oligonucleotide, $250 \mathrm{nM}$ of the Gabra 5 predesigned probe (TaqMan®, Applied Biosystems ${ }^{\circledR}$, Foster City, CA) and $10 \mu \mathrm{l}$ of cDNA (dilution 1:4). Amplification was performed in the CFX96 real-time PCR detection system equipment (Bio-Rad, Hercules, CA) as follows: an initial step of $50^{\circ} \mathrm{C}$ for $2 \mathrm{~min}$ and $95^{\circ} \mathrm{C}$ for $10 \mathrm{~min}$, followed by 60 cycles of $92^{\circ} \mathrm{C}$ for $15 \mathrm{~s}$ and a final step of $60^{\circ} \mathrm{C}$ for $1 \mathrm{~min}$. The messenger RNA (mRNA) expression was quantified by the $2^{\Delta \Delta \mathrm{ct}}$ method normalized to r18S (Applied Biosystems ${ }^{\circledR}$ TaqMan® Ribosomal RNA Control Reagents, Foster City, CA).

\section{Immunohistochemistry}

Rats were euthanized with $\mathrm{CO}_{2}$ and perfused intra-aortically with $300 \mathrm{~mL}$ of ice-cold, oxygenated artificial cerebrospinal fluid (ACSF) [containing (mM): $\mathrm{NaCl} 125, \mathrm{KCl} 2.5$, 
$\mathrm{CaCl}_{2} 2.5, \mathrm{MgCl}_{2} 2, \mathrm{NaHCO}_{3} 26, \mathrm{NaH}_{2} \mathrm{PO}_{4} 1.25$, and glucose 25], $\mathrm{pH} 7.4$, at a flow rate of $18-25 \mathrm{~mL} / \mathrm{min}$. Animals were decapitated, the spinal cord obtained by hydro-extrusion with ice-cold ACSF and the ipsilateral L5 DRGs were excised. The lumbar section and the DRGs were dropped into ice-cold freshly prepared fixative [4\% paraformaldehyde dissolved in $0.15 \mathrm{M}$ sodium phosphate buffer, $\mathrm{pH}$ 7.4] and post-fixed during $60 \mathrm{~min}$, rinsed with phosphate buffer (PBS), cryoprotected by $72 \mathrm{~h}$ in $30 \%$ sucrose in PBS, embedded in OCT compound (Tissue-Tek; Sakura Finetek, Torrance, CA), frozen with dry ice and stored at $-80^{\circ} \mathrm{C}[49]$.

Sections were cut from frozen blocks with a cryostat at a thickness of $30 \mu \mathrm{m}$ for the spinal cord and $12 \mu \mathrm{m}$ for the DRGs. The sections were mounted onto gelatin-coated slides. Pappen (Super Pap-Pen, Cat. \# h2802, EB Sciences, East Granby, CT) was used to draw a hydrophobic ring around the sections and the slides were allowed to air-dry overnight at room temperature. Sections were first washed 3 times with TBS + 0.2\% TX-100 pH 7.4, followed by 2 washes of 5 min each with $0.5 \%$ of sodium borohydride $\left(\mathrm{NaBH}_{4}\right.$, Cat. \# 102894, MP Biomedicals, Santa Ana, CA), followed by a blocking step with 4\% normal donkey serum in TBS $+0.2 \%$ TX-100 for $1 \mathrm{~h}$. Finally, the sections were incubated in blocking solution with the primary antibodies overnight at $4^{\circ} \mathrm{C}$. Immunodetection of $\mathrm{a}_{5^{-}}$ $\mathrm{GABA}_{\mathrm{A}}$ receptors in the spinal cord was performed using an antibody generously provided by Dr. Jean-Marc Fritschy (dilution 1:3000) raised against extracellular epitopes located on the N-terminal segment of proteins in guinea pig serum [26]. Specificity of this antibody has been recently reported using conditional Gabra5 knock-out mice [60].

For immunodetection in DRGs, we used an antibody for the $a_{5}-\mathrm{GABA}_{\mathrm{A}}$ receptors (rabbit anti- $a_{5}-G_{B B A}$, Cat. \# SAB2100878; dilution 1:200, Sigma-Aldrich, St. Louis, MO) [41]. In order to determine the specific cellular and subcellular distribution of the $a_{5}-G_{A B A}$ receptors in the spinal cord and DRG, we performed double staining with the following markers: NeuN was used as a specific neuronal marker (chicken anti-NeuN, Cat. \# ABN91, dilution 1:1000, Millipore, Bilerica, MA); CGRP was used as a specific marker of peptidergic neurons (goat anti-CGRP, Cat. \# Ab36001, dilution 1:1000, Abcam, Cambridge, MA); Lectin IB4 conjugated to AlexaFluor 647 (anti-IB4-AlexaFluor 647, Cat. \# I32450, dilution 1:2000, Molecular Probes, Eugene, OR) was used to label non-peptidergic neurons; Iba1 was used to identify microglia (rabbit anti-Iba1, Cat. \# 019-19741, dilution 1:1000, Wako, Richmond, VA), and GFAP was used to identify astrocytes (mouse anti-GFAP, Cat. \# C9205, dilution 1:2000, Sigma Aldrich, St. Louis, MO). Sections were washed in TBS $+0.2 \% \mathrm{TX}-100$ and incubated for $60 \mathrm{~min}$ at room temperature with the corresponding secondary antibodies conjugated to $\mathrm{Cy} 3\left(\mathrm{Cy}^{\mathrm{TM}} 3\right.$ AffiniPure Donkey Anti-Guinea Pig IgG [H $+\mathrm{L}$, Cat. \# 706-165-148, dilution 1:1000, Jackson ImmunoResearch, West Grove, PA) and/or Alexa 488 (Donkey anti-Goat $\operatorname{IgG}(\mathrm{H}+\mathrm{L})$ secondary antibody, Alexa Fluor 488 conjugate, Cat. \# A-11055, dilution 1:1000, Invitrogen, Carlsbad, CA), and/or Alexa 549 (Donkey anti-Rabbit IgG $[\mathrm{H}+\mathrm{L}]$ secondary antibody, Alexa Fluor 594 conjugate, Cat. \# A-21207, dilution 1:1000, Invitrogen, Carlsbad, CA). Sections were washed again and cover-slipped with ProLong® Gold antifade reagent with DAPI (Life technologies, Carlsbad, CA). 


\section{Immunofluorescence and confocal microscopy}

Fluorescence images were captured using an immunofluorescence microscope (Zeiss AxioImager M2 Microscope, Irvine, CA) at the same exposure settings and fluorescent lamp intensity using 10x and 20x objectives and with the use of Stereo investigator software (MBF Bioscience, Williston, VT). Mosaic images were captured from dorsal spinal cord at the desired wavelength/spectrum of light from each independent channel in order to obtain the best focal plane. Image $\mathrm{J}$ was used to perform the desired merge for each doublestaining. Confocal images were taken using an Olympus FV1000 microscope (Olympus FluoView FV1000 Confocal Microscope, Melville, NY) with 63X oil immersion. In all cases sequential scanning with the 488,543 , and $647 \mathrm{~nm}$ laser lines was used to capture a random scan field (2-17 optical layers, z-separation $0.2-0.5 \mu \mathrm{M}$ ) and visualized in FV10ASW, version 4 software (Olympus, Tokyo). Image $\mathbf{J}$ was used to construct images from 1 optical layer to show co-localization between the structures of interest in the respective double-staining.

To determine percentages of DRG neuron subpopulations, five randomly selected sections were counted for the number of labeled neurons as a percentage of the total (NeuN) neurons. Neuron sizes were determined manually using Image $\mathbf{J}$ software. For histological quantification of immunostained DRG and spinal cord sections, 5 sub-serial L4-L6 segments of spinal cord and L5 DRG sections were used. Mean fluorescence intensity and positivelystained elements were determined using Image J software [50, 69].

\section{Rate-dependent depression of the Hoffmann reflex}

The Hoffmann reflex was recorded as previously described [9,35]. Briefly, under ketamine anesthesia $(100 \mathrm{mg} / \mathrm{kg} / \mathrm{h}, \mathrm{i} . \mathrm{m}$.), the right hind limb of the animal was secured and a pair of stimulating needle electrodes were inserted transcutaneously into the surroundings of the tibial nerve. For recording, a pair of silver needle electrodes was inserted into the interosseous muscles between the fourth and the fifth, or the first and the second metatarsal muscles of the right hind paw, and a grounding electrode was placed into the tail. The tibial nerve was stimulated using square pulses with increasing intensity $(0.1-10 \mathrm{~mA}$ in $0.5 \mathrm{~mA}$ increments, $0.1 \mathrm{~Hz}, 0.2 \mathrm{~ms}$, Isostim A320, WPI Inc., Sarasota, FL). Responses were recorded with an A/C-coupled differential amplifier (Model DB4; DPI, Sarasota, FL) and used to determine the intensity necessary to obtain a maximal $\mathrm{M}$ and $\mathrm{H}$ response. Then, we used this intensity to apply trains of 20 pulses at $0.1,0.5,1,5$ and $10 \mathrm{~Hz}$ in order to measure rate-dependent depression (RDD) of the Hoffmann reflex and changes in RDD at different stimulation frequencies. We used the $1 \mathrm{~Hz}$ stimulation frequency for data analysis. This frequency was chosen because it was associated with an approximately $40 \%$ decrease in the amplitude of the $\mathrm{H}$-wave between the first and second stimulus in normal rats [39]. These allow detection of subsequent increase or attenuation in response to drug administration. RDD of the Hoffmann reflex was calculated as the percent change in the amplitude of the $\mathrm{H}$ wave (\% Baseline H reflex) evoked by the second stimulation (H2) compared to the H-wave amplitude evoked by the first stimulus (H1).

\section{Data analysis and statistics}

Behavioral data are expressed as mean $\pm \operatorname{SEM}(\mathrm{n} \ 6)$ of the hind paw withdrawal response. 
qPCR data are expressed as $\mathrm{a}_{5}-\mathrm{GABA}_{\mathrm{A}}$ receptors mRNA relative expression normalized with r18S. mRNA data are expressed as the mean \pm SEM of 3 independent animals.

The histological data are expressed as the mean \pm SEM of the $a_{5}$ or NeuN positive neurons plotted as \% of total DRG L5 neurons depending of the size or as the $\alpha_{5}$ mean fluorescence intensity.

RDD of the Hoffmann reflex and the effect of treatment are expressed as the mean \pm SEM of 5 independent animals and plotted as $\%$ of baseline $\mathrm{H}$ reflex.

Statistical differences between groups were determined by one- or two-way analysis of variance (ANOVA), followed by the Student-Newman-Keuls test for post-hoc comparison. $P$ values less than $0.05(P<0.05)$ were considered significant.

\section{Results}

\section{Peripheral and spinal $a_{5}-G A B A_{A}$ receptors are involved in formalin-induced secondary allodynia and hyperalgesia}

Local peripheral ipsilateral, but not contralateral, pre-treatment with the $a_{5}-\mathrm{GABA}_{\mathrm{A}}$ receptors partial agonist $\mathrm{L}-838,417$ increased $0.5 \%$ formalin-induced secondary hyperalgesia $\left(\mathrm{F}_{7,44}=17.323, \mathrm{P}=0.001\right)$ (Fig. $\left.1 \mathrm{~A}\right)$. In contrast, the same treatment did not modify secondary allodynia. In order to investigate if the peripheral pronociceptive effect of L-838,417 was due to activation of $a_{5}-\mathrm{GABA}_{\mathrm{A}}$ receptors, we studied the effects of this agonist in presence of the $\mathrm{a}_{5}-\mathrm{GABA}_{\mathrm{A}}$ receptors antagonist L-655,708. $\mathrm{L}-655,708(0.5 \mathrm{nmol} /$ paw) completely prevented L-838,417-induced increase in secondary hyperalgesia $\left(F_{4,28}=27.433, \mathrm{P}=0.001\right)$ (Fig. 1B). The above dose of antagonist, which did not affect formalin-induced secondary allodynia and hyperalgesia per se (Fig. 1B), is supposed to completely block $\mathrm{a}_{5}-\mathrm{GABA}_{\mathrm{A}}$ receptors [66].

In order to investigate whether the $\mathrm{a}_{5}-\mathrm{GABA}_{\mathrm{A}}$ receptors are involved in development of formalin-induced mechanical secondary allodynia and hyperalgesia, we assessed the effect of pre-treatment with L-655,708. Ipsilateral, but not contralateral, local peripheral pretreatment with L-655,708 $(0.15-15 \mathrm{nmol} / \mathrm{paw})$ prevented $1 \%$ formalin-induced secondary allodynia $\left(\mathrm{F}_{5,30}=6.553, \mathrm{P}=0.001\right)$ and hyperalgesia $\left(\mathrm{F}_{5,30}=10.733, \mathrm{P}=0.001\right)$ at 6 days postformalin injection (Fig. 2A). Moreover, intrathecal (10 $\mu$, into the subarachnoid space) pretreatment with L-655,708 $(0.15-15 \mathrm{nmol} / \mathrm{rat})$, but not vehicle (20\% DMSO), prevented secondary allodynia $\left(\mathrm{F}_{4,31}=8.388, \mathrm{P}=0.001\right)$ and hyperalgesia $\left(\mathrm{F}_{4,31}=14.906, \mathrm{P}=0.001\right)$ at the days post-formalin injection (Fig. 2B). Interestingly, ipsilateral, but not contralateral, peripheral pre-treatment with the greatest dose of $\mathrm{L}-655,708(15 \mathrm{nmol} / \mathrm{paw})$ also prevented formalin-induced secondary allodynia $\left(\mathrm{F}_{2,16}=23.969, \mathrm{P}=0.001\right)$ and hyperalgesia $\left(\mathrm{F}_{2,16}=34.592, \mathrm{P}=0.001\right)$ at 3 days post-formalin injection (Supplementary Fig. 1A). Likewise, intrathecal pre-treatment with L-655,708 (15 nmol/rat) avoided formalin-induced secondary allodynia, $\left(\mathrm{F}_{2,16}=14.039, \mathrm{P}=0.001\right)$ and hyperalgesia $\left(\mathrm{F}_{2,15}=11.575, \mathrm{P}=0.001\right)$ at 3 days post-formalin injection (Supplementary Fig. 1B). 
In order to investigate whether the $a_{5}-\mathrm{GABA}_{\mathrm{A}}$ receptors are involved in maintenance of formalin-induced mechanical secondary allodynia and hyperalgesia, we studied the effect of L-655,708 (0.15-15 nmol) as post-treatment (6 days after formalin injection). The effect was assessed $1 \mathrm{~h}$ after drug injection. In these conditions, local peripheral (Fig. 3A, allodynia: $\mathrm{F}_{5,28}=11.933, \mathrm{P}=0.001$; hyperalgesia: $\mathrm{F}_{5,28}=21.018, \mathrm{P}=0.001$ ) or intrathecal (Fig. 3B, allodynia: $\mathrm{F}_{4,22}=7.283, \mathrm{P}=0.001$; hyperalgesia: $\mathrm{F}_{4,22}=10.698$, $\mathrm{P}=0.001$ ) administration of L-655,708 reversed formalin-induced long-lasting secondary allodynia and hyperalgesia. Furthermore, local peripheral (Supplementary Fig 2A, allodynia, $\mathrm{F}_{3,20}=13.375, \mathrm{P}=0.001$; hyperalgesia, $\mathrm{F}_{3,20}=17.863, \mathrm{P}=0.001$ ) or intrathecal (Supplementary Fig $2 \mathrm{~B}$, allodynia, $\mathrm{F}_{2,15}=41.155, \mathrm{P}=0.001$; hyperalgesia, $\left.\mathrm{F}_{2,15}=54.076, \mathrm{P}=0.001\right)$ post-treatment, at 3 days after formalin injection, with the greatest dose of L-655,708 (15 nmol) reversed formalin-induced secondary allodynia and hyperalgesia. Neither vehicle nor contralateral treatment, at the greatest dose used, modified formalin-induced long-lasting nociceptive behaviors, suggesting a drug-specific effect as well as a local peripheral effect, respectively. Also, intrathecal pre-treatment (Supplementary Fig. 3A) or post-treatment (Supplementary Fig. 3B) with L-655,708 $(15 \mathrm{nmol})$ did not have any effect in naïve rats.

To further demonstrate that $\mathrm{a}_{5}-\mathrm{GABA}_{\mathrm{A}}$ receptors participate in chronic nociception, we determined the effects of post-treatment with L-655,708 in rats injected with CFA or subjected to spinal nerve ligation at different times. As in the formalin model, the effect was assessed $1 \mathrm{~h}$ after drug injection. Intraplantar injection of CFA or L5/L6 spinal nerve ligation diminished withdrawal threshold from $\sim 14$ to $\sim 3 \mathrm{~g}$, which was interpreted as tactile allodynia. Intrathecal injection of L-655,708 (15 nmol) at 3, 7 and 14 days after CFA injection reversed tactile allodynia (Fig. $4, \mathrm{~F}_{3,25}=47.81$, $\mathrm{p}=0.0001$ ). This intrathecal dose was also able to reverse spinal nerve ligation-induced tactile allodynia at the same time points after nerve injury (Fig. 5, $\mathrm{F}_{4,24}=222.6, \mathrm{p}=0.001$ ).

\section{Expression of $a_{5}-G_{A B A}$ receptors in spinal cord and DRG}

Pharmacological data suggest the presence of $\mathrm{a}_{5}-\mathrm{GABA}_{\mathrm{A}}$ receptors in DRG and spinal cord. Thus, we measured their expression in rats at $1 \mathrm{~h}$ and 1,3 and 6 days after $1 \%$ formalin injection by qPCR. $a_{5}-\mathrm{GABA}_{\mathrm{A}}$ receptors mRNA was detected in the ipsilateral dorsal spinal cord and L4-L6 DRGs (Fig. 6). In addition, formalin injection increased $a_{5}-G_{A B A}$ receptors mRNA levels mainly at 3 days after formalin injection in dorsal spinal cord $\left(\mathrm{F}_{4,15}=10.26, \mathrm{P}=0.001\right)$ and $\mathrm{DRG}\left(\mathrm{F}_{4,15}=4.07, \mathrm{P}=0.02\right)$ (Fig. 6).

\section{Distribution of $a_{5}-G A B A_{A}$ receptors in dorsal horn, $D R G$ and peripheral afferent fibers}

Based on our pharmacological and molecular results, we decided to investigate the distribution of $\mathrm{a}_{5}-\mathrm{GABA}_{\mathrm{A}}$ receptors in dorsal horn spinal cord, DRG and peripheral axons. In agreement with previous reports $[9,53]$, we found $a_{5}-\mathrm{GABA}_{\mathrm{A}}$ receptors immunoreactivity mainly in lamina II, III, IV of the dorsal horn (Fig. 7A). Furthermore, histological analysis revealed the presence of $\mathrm{a}_{5}-\mathrm{GABA}_{\mathrm{A}}$ receptors in neuronal bodies and neuropil suggesting their presence in specific subsets of neurons and in primary afferent fibers (Figs. 7A/7B). As reported in turtles [41], there was $\mathrm{a}_{5}-\mathrm{GABA}_{\mathrm{A}}$ receptors immunoreactivity in DRG (Figs. 7C/7D) and peripheral afferent fibers of the rat (Figs. 7E/7F). Of note, $1 \%$ formalin enhanced $\mathrm{a}_{5}-\mathrm{GABA}_{\mathrm{A}}$ receptors fluorescence intensity in dorsal spinal cord (Figs. 8A-B, 
$\mathrm{F}_{2,6}=17.42, \mathrm{P}=0.001$ ) and L5 DRG (Figs. $8 \mathrm{C}-\mathrm{D}, \mathrm{F}_{2,12}=30.19, \mathrm{P}=0.001$ ) at 3 and 6 days after injection.

\section{Expression pattern of $a_{5}-G A B A_{A}$ receptors in dorsal horn}

In order to investigate the expression pattern of $a_{5}-\mathrm{GABA}_{\mathrm{A}}$ receptors, we performed multiple immunolabeling experiments in defined cellular compartments of the dorsal horn. These included neuronal bodies (NeuN), peptidergic (CGRP) and non-peptidergic (IB4) small afferent terminals as well as astrocytes (GFAP) and microglia (Iba1). The specificity of the primary antibodies was confirmed through the immunostaining in the absence of the respective primary antibodies (data not shown). We observed specific neuronal staining for $\mathrm{NeuN}$ in the dorsal horn that co-localized with that of $\mathrm{a}_{5}-\mathrm{GABA}_{\mathrm{A}}$ receptors (Figs. 9A-D). We did not observe co-localization of $a_{5}-G_{A B A}$ receptors with CGRP suggesting that these receptors are absent in peptidergic terminals (Figs. $9 \mathrm{E}-\mathrm{H}$ ). In contrast, $\mathrm{a}_{5}-\mathrm{GABA}_{\mathrm{A}}$ receptors co-localized with IB4 suggesting their presence in non-peptidergic afferent terminals (Figs. 9I-L). $a_{5}-\mathrm{GABA}_{\mathrm{A}}$ receptors did not co-localize with GFAP (Figs. 9M-P) nor Iba1 (Figs. 9Q-T) suggesting their absence in astrocytes and microglia, respectively.

\section{Expression pattern of $a_{5}-G_{A B A}$ receptors in DRG and axons}

The same staining combinations were performed in DRG. Consistently with the dorsal horn co-labeling, $a_{5}-\mathrm{GABA}_{\mathrm{A}}$ receptors were observed in small- and medium-sized body neurons (Figs. 10A-D), peptidergic (Figs. 10E-H, 54.7\% \pm 4.6) and non-peptidergic (Figs. 10I-L, $77.3 \% \pm 4.6)$ neurons. $a_{5}-\mathrm{GABA}_{\mathrm{A}}$ receptors did not co-localize with GFAP suggesting that these receptors are absent in satellite cells (Figs. 10M-P). $a_{5}-\mathrm{GABA}_{\mathrm{A}}$ receptors immunoreactivity was mainly found in small- and medium-size DRG neurons (Fig. 11).

\section{Formalin injection produces GABAergic disinhibition}

It has been proposed that $\mathrm{RDD}$, mediated by $\mathrm{GABA}_{\mathrm{A}}$ receptors in normal rats, may be used as a maneuver to investigate alterations in pre- and post-synaptic GABAergic inhibition produced during neuropathic pain [34,35,39]. We, therefore, decided to determine whether RDD of the Hoffmann reflex is modified by formalin injection and the involvement of $\mathrm{a}_{5^{-}}$ $\mathrm{GABA}_{\mathrm{A}}$ receptors in this action. RDD of the Hoffmann reflex was determined at 1, 3 and 6 days after formalin injection. In order to avoid the effect of repetitive electrode insertions, 5 independent groups were used. M-waves were unchanged by stimulation in both vehicleand formalin-treated rats (data not shown). In contrast, formalin injection impaired the reduction of the RDD of the Hoffmann reflex 6 days after injection, compared to the control group (Figs. 12A-B, $\mathrm{F}_{3,130}=10.41, \mathrm{P}=0.0001$ ). As reported earlier [2], long-lasting secondary allodynia and hyperalgesia was well established at this time after formalin injection. Amplitude of the Hoffmann reflex (H1) was not significantly modified by the formalin injection at any day, suggesting that formalin did not alter the intrinsic excitability of motor neurons (Fig 12C). In contrast, formalin clearly induced a time-dependent impairment of RDD of the Hoffmann reflex (Fig. 12D, $\mathrm{F}_{4,40}=21.6, \mathrm{P}=0.001$ ). 


\section{L-655,708 restores RDD of the Hoffmann reflex in formalin-treated rats}

Formalin-treated rats showed long-lasting secondary allodynia/hyperalgesia and impairment of the RDD of the Hoffmann reflex 6 days post-injection. This phenotype is similar to that observed after spinal cord injury or neuropathic pain in rats [39,58]. Since the selective $a_{5^{-}}$ $\mathrm{GABA}_{\mathrm{A}}$ receptors antagonist L-655,708 prevented and reversed long-lasting formalininduced secondary allodynia and hyperalgesia, we investigated its effect on RDD of the Hoffmann reflex in formalin-treated rats (Fig. 13). Both intrathecal pre-treatment $\left(\mathrm{F}_{3,14}=5.97, \mathrm{P}=0.008\right.$, Fig. 13B $)$ and post-treatment $\left(\mathrm{F}_{3,17}=10.05\right.$, $\mathrm{P}=0.001$, Fig. 13C $)$ with L-655,708 prevented and reversed, respectively, formalin-induced alteration of RDD of the Hoffmann reflex.

\section{Discussion}

\section{Role of $a_{5}-G_{A B A}$ receptors in formalin-induced secondary allodynia and hyperalgesia}

Here we show that $a_{5}-G A B A_{A}$ receptors, located at peripheral and spinal sites, are involved in formalin-induced long-lasting secondary allodynia and hyperalgesia. This conclusion is based on the following observations: i) local peripheral injection of L-838,417 $\left(a_{2^{-}}, a_{3^{-}}\right.$and $a_{5}-G_{A B A}$ receptor partial agonist) increased formalin-induced long-lasting secondary hyperalgesia; ii) local peripheral L-655,708 (selective $\mathrm{a}_{5}-\mathrm{GABA}_{\mathrm{A}}$ receptor antagonist) diminished the pronociceptive effect of L-838,417; iii) local peripheral or intrathecal injection of L-655,708 prevented and reversed long-lasting formalin-induced hypersensitivity; and iv) local peripheral or intrathecal injection of L-655,708 was effective at 3 and 6 days after formalin injection. To our knowledge, this is the first report showing that peripheral and spinal $a_{5}-\mathrm{GABA}_{\mathrm{A}}$ receptors play a role in the development and maintenance of the long-lasting secondary hypersensitivity. Our data extend previous observations showing that local peripheral $\mathrm{GABA}_{\mathrm{A}}$ receptors agonists increase formalininduced acute nociception and those effects are prevented by the peripheral injection of bicuculline or L-655,708 [11]. In contrast, it has been reported that L-838,417 reduces incision-induced mechanical and thermal hyperalgesia [59]. Though the reason for this discrepancy is unknown, the antinociceptive effect induced by L-838,417 could be mediated via the $\alpha_{2}$ and/or $\alpha_{3}$ subunits [23,36,37,52,59], whereas the pronociceptive effect may be mediated via the $a_{5}$ subunit (this study). In support of our data, intrathecal administration of L-655,708 reversed CFA- or nerve injury-induced tactile allodynia at 3, 7 and 14 days. These data suggest that $\mathrm{a}_{5}-\mathrm{GABA}_{\mathrm{A}}$ receptors are also involved in the development and maintenance of other chronic inflammatory and neuropathic pain models.

The role of $\mathrm{GABA}_{\mathrm{A}}$ receptors in chronic pain is a matter of debate. In naïve animals, $\mathrm{GABA}_{\mathrm{A}}$ receptors agonists and antagonists produce antinociception and pronociception, respectively $[5,24,65]$. However, tissue or nerve injury appears to switch $\mathrm{GABA}_{\mathrm{A}}$ receptors function $[18,19,55]$. Our results indicate that the $\mathrm{a}_{5}-\mathrm{GABA}_{\mathrm{A}}$ receptors antagonist $\mathrm{L}-655,708$ produces antinociception implying that GABAergic inhibition might be switched to excitation and/or loss of inhibition [16,55,74,75]. It is worth noting that extrasynaptic $a_{5^{-}}$ $\mathrm{GABA}_{\mathrm{A}}$ receptors are present in DRG and axons [20,22,48]. In those sites, these receptors could be tonically activated by low extracellular GABA concentrations [25] leading to a tonic state of excitability and lowering the threshold for activation of the dorsal root reflex 
[41]. In such conditions, the $a_{5}-\mathrm{GABA}_{\mathrm{A}}$ receptors antagonist L-655,708 could diminish dorsal root reflexes [41] or restore GABAergic inhibition. The net effect could be a reduced excitability of the primary afferents. In support of this, there is evidence that dorsal root reflexes that follow $\mathrm{GABA}_{\mathrm{A}}$ receptors activation in the spinal cord also occur in the periphery [13].

\section{Expression of $a_{5}-G_{A B A}$ receptors}

Besides the pharmacological evidence, our study demonstrates that $\mathrm{a}_{5}-\mathrm{GABA}_{\mathrm{A}}$ receptors mRNA is expressed in the dorsal spinal cord and DRG of naïve rats (Fig. 6). This result agrees with previous observations showing expression of $a_{5}-\mathrm{GABA}_{\mathrm{A}}$ receptors in those sites $[11,54,41,45]$. Further, formalin injection increased $a_{5}-G_{A B A}$ receptors mRNA expression in the dorsal spinal cord and DRG of rats mainly at 3 days post-injury. Other studies have reported that peripheral axotomy also enhances $\mathrm{a}_{5}-\mathrm{GABA}_{\mathrm{A}}$ receptors expression but at longer times (14 and 28 days) [71,73]. Differences in the time to increase $a_{5}-G_{A B A}$ receptors mRNA expression could be due to the model (formalin test versus nerve axotomy). Our results suggest that the transient modulation of $a_{5}-\mathrm{GABA}_{\mathrm{A}}$ receptors could be required for the initiation but also for maintenance of the hypersensitivity. In support of this, behavioral data showed that $\mathrm{a}_{5}-\mathrm{GABA}_{\mathrm{A}}$ receptors play a role in development and maintenance of chronic nociception.

Immunofluorescence studies reveal that $\mathrm{a}_{5}-\mathrm{GABA}_{\mathrm{A}}$ receptors are localized in laminae II-IV, DRG and primary afferent fibers. Their presence in DRG has been reported previously $[6,29,41,53,54,64]$. Interestingly, formalin increased fluorescence intensity in dorsal spinal cord and DRG at 3 and 6 days after injection. These data agree with the enhancement of $a_{5^{-}}$ $\mathrm{GABA}_{\mathrm{A}}$ receptors mRNA expression and suggest that these receptors are important in the development and maintenance or formalin-induced hypersensitivity.

We observed immunoreactivity in multipolar neurons that were NeuN-positive and neuropil within non-peptidergic fibers in the dorsal horn. A similar pattern was obtained in DRGs confirming that $\mathrm{a}_{5}-\mathrm{GABA}_{\mathrm{A}}$ receptors are present in small- to medium-size non-peptidergic neurons. We also observed co-localization of $a_{5}-G_{A B A}$ receptors with CGRP, suggesting that these receptors are present in some peptidergic neurons. To our knowledge, this is the first report describing the presence of extrasynaptic $\mathrm{a}_{5}-\mathrm{GABA}_{\mathrm{A}}$ receptors in non-peptidergic and, at a lesser extent, peptidergic neurons in dorsal spinal cord and DRG.

\section{Contribution of $a_{5}-G A B A_{A}$ receptors to formalin-induced loss of the RDD of the Hoffmann reflex}

In order to address how GABAergic signaling was participating in the development and maintenance of long-lasting secondary allodynia and hyperalgesia, we used the RDD of the Hoffmann reflex as a paradigm. Interestingly, formalin injection impaired, in a timedependent fashion, the RDD of the Hoffmann reflex. A similar effect has been reported in spinal cord injured and diabetic rats [34,58] and it has been attributed to the inversion of the $\mathrm{GABA}_{\mathrm{A}}$ receptors function [35,39]. It has been reported that extrasynaptic $\mathrm{GABA}_{\mathrm{A}}$ receptors mediate tonic inhibition in substantia gelatinosa neurons $[67,68]$ and in primary afferents terminals [41]. The most likely subunit composition of $\mathrm{GABA}_{\mathrm{A}}$ receptors in 
substantia gelatinosa neurons mediating tonic inhibition may be $\alpha_{5} \beta_{\mathrm{x}} \gamma_{2}[4,67]$. Furthermore, the charge transfer by the GABAergic tonic current in substantia gelatinosa neurons has been estimated to be 6 times of that carried by phasic inhibition [4], which is similar to that reported in hippocampus and cerebral neurons [25] and suggests a role for tonic inhibition in modulation of neuron excitability. The switch from tonic inhibition to excitation and/or loss of function could disrupt neuronal network activity involved in the control of nociceptive information. Our finding that blockade of $a_{5}-G_{A B A}$ receptors restores the RDD of the Hoffmann reflex suggest that these receptors contribute to $\mathrm{GABA}_{\mathrm{A}}$ receptors-mediated tonic inhibition switching to excitation and/or loss of function in the long-lasting nociception induced by formalin and, likely, CFA or nerve injury.

At the pre-synaptic level, extrasynaptic $a_{5}-G_{A B A}$ receptors may contribute to these behaviors by tonically depolarizing the axonal membrane, without altering the primary afferent depolarization [41] and facilitating the dorsal root reflex activity which might be reinforced with an over-expression of NKCC1 [31,47]. At the post-synaptic level, extrasynaptic $a_{5}-G_{B B} A_{A}$ receptors would tonically depolarize second order neurons contributing to long-lasting nociception. An alternative hypothesis would be that $a_{5}-G_{B B A}$ receptors, on primary afferents, drive increased spinal input and brain derived neurotrophic factor (BDNF) release. Elevated synaptic BDNF drives depression of post-synaptic KCC2 expression and thus the switch to GABA-driven excitation [34]. In support of this, our immunofluorescence studies showed a broad presence of this receptor in dorsal horn neurons and DRG while formalin injection increased $a_{5}-G_{B B A}$ receptors fluorescence intensity.

In conclusion, our study shows that peripheral and spinal extrasynaptic $a_{5}-G_{A B A}$ receptors play an important role in formalin-induced GABAergic disinhibition and longlasting secondary hypersensitivity. Spinal extrasynaptic $a_{5}-G_{A B A}$ receptors also participate in the maintenance of chronic nociception induced by CFA or spinal nerve ligation.

\section{Supplementary Material}

Refer to Web version on PubMed Central for supplementary material.

\section{Acknowledgments}

This work is part of the Ph.D. dissertation of Mariana Bravo-Hernández. Authors are grateful with Dr. Jean-Marc Fritschy (University of Zurich) for the generous gift of the a5 subunit-containing GABAA receptor antibody. We greatly appreciate the technical assistance of Michael R. Navarro, Guadalupe C. Vidal-Cantú and Mercedes C. Urbán-Nuñez. Mariana Bravo-Hernández, Jorge B. Pineda-Farias and Paulino Barragán-Iglesias are Conacyt fellows. Ricardo González-Ramírez was supported by a post-doctoral fellowship from Conacyt (CB-2012/179294). This work was partially supported by Conacyt (CB-2012/179294 to VG-S, RF and RD-L) and NIH (DK057629 to NAC) grants.

\section{References}

1. Ambriz-Tututi M, Cruz SL, Urquiza-Marín H, Granados-Soto V. Formalin-induced long-term secondary allodynia and hyperalgesia are maintained by descending facilitation. Pharmacol Biochem Behav. 2011; 98:417-24. [PubMed: 21334366] 
2. Ambriz-Tututi M, Rocha-González HI, Castañeda-Corral G, Araiza-Saldaña CI, Caram-Salas NL, Cruz SL, Granados-Soto V. Role of opioid receptors in the reduction of formalin-induced secondary allodynia and hyperalgesia in rats. Eur J Pharmacol. 2009; 619:25-32. [PubMed: 19686723]

3. Anseloni VC, Gold MS. Inflammation-induced shift in the valence of spinal GABA $\mathrm{A}$ receptormediated modulation of nociception in the adult rat. J Pain. 2008; 9:732-38. [PubMed: 18467182]

4. Ataka T, Gu JG. Relationship between tonic inhibitory currents and phasic inhibitory activity in the spinal cord lamina II region of adult mice. Mol Pain. 2006; 2:36. [PubMed: 17129385]

5. Baba H, Ji RR, Kohno T, Moore KA, Ataka T, Wakai A, Okamoto M, Woolf CJ. Removal of GABAergic inhibition facilitates polysynaptic A fiber-mediated excitatory transmission to the superficial spinal dorsal horn. Mol Cell Neurosci. 2003; 24:818-30. [PubMed: 14664828]

6. Barolet AW, Kish SJ, Morris ME. Identification of extrasynaptic binding sites for $\left[{ }^{3} \mathrm{H}\right]-\mathrm{GABA}$ in peripheral nerve. Brain Res. 1985; 358:104-9. [PubMed: 3000511]

7. Belelli D, Harrison NL, Maguire J, Macdonald RL, Walker MC, Cope DW. Extrasynaptic GABA A receptors: form, pharmacology, and function. J Neurosci. 2009; 29:12757-63. [PubMed: 19828786]

8. Bohlhalter S, Weinmann O, Mohler H, Fritschy JM. Laminar compartmentalization of GABA $\mathrm{A}^{-}$ receptor subtypes in the spinal cord: an immunohistochemical study. J Neurosci. 1996; 16:283-97. [PubMed: 8613794]

9. Boulenguez P, Liabeuf S, Bos R, Bras H, Jean-Xavier C, Brocard C, Stil A, Darbon P, Cattaert D, Delpire E, Marsala M, Vinay L. Down-regulation of the potassium-chloride cotransporter KCC2 contributes to spasticity after spinal cord injury. Nat Medicine. 2010; 16:302-7.

10. Bravo-Hernández M, Cervantes-Durán C, Pineda-Farías JB, Barragán-Iglesias P, López-Sánchez P, Granados-Soto V. Role of peripheral and spinal 5- $\mathrm{HT}_{3}$ receptors in development and maintenance of formalin-induced long-term secondary allodynia and hyperalgesia. Pharmacol Biochem Behav. 2012; 101:246-57. [PubMed: 22289689]

11. Bravo-Hernández M, Feria-Morales LA, Torres-López JE, Cervantes-Durán C, Delgado-Lezama R, Granados-Soto V, Rocha-González HI. Evidence for the participation of peripheral $a_{5}$ subunitcontaining $\mathrm{GABA}_{\mathrm{A}}$ receptors in $\mathrm{GABA}_{\mathrm{A}}$ agonists-induced nociception in rats. Eur $\mathrm{J}$ Pharmacol. 2014; 734:91-7. [PubMed: 24726872]

12. Caram-Salas NL, Reyes-García G, Bartoszyk GD, Araiza-Saldaña CI, Ambriz-Tututi M, RochaGonzález HI, Arreola-Espino R, Cruz SL, Granados-Soto V. Subcutaneous, intrathecal and periaqueductal grey administration of asimadoline and ICI-204448 reduces tactile allodynia in the rat. Eur J Pharmacol. 2007; 573:75-83. [PubMed: 17643411]

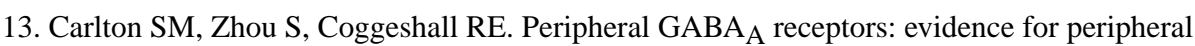
primary afferent depolarization. Neuroscience. 1999; 93:713-22. [PubMed: 10465455]

14. Castro A, Aguilar J, González-Ramírez R, Loeza-Alcocer E, Canto-Bustos M, Felix R, DelgadoLezama $R$. Tonic inhibition in spinal ventral horn interneurons mediated by a subunit-containing GABA $_{A}$ receptors. Biochem Biophys Res Commun. 2011; 412:26-31. [PubMed: 21798246]

15. Cervantes-Durán C, Pineda-Farías JB, Bravo-Hernández M, Quiñonez-Bastidas GN, Vidal-Cantú GC, Barragán-Iglesias P, Granados-Soto V. Evidence for the participation of peripheral 5- $\mathrm{HT}_{2 \mathrm{~A}}, 5$ $\mathrm{HT}_{2 \mathrm{~B}}$, and $5-\mathrm{HT}_{2 \mathrm{C}}$ receptors in formalin-induced secondary mechanical allodynia and hyperalgesia. Neuroscience. 2013; 232:169-81. [PubMed: 23219842]

16. Cervero F, Laird J, García-Nicas E. Secondary hyperalgesia and presynaptic inhibition: an update. Eur J Pain. 2003; 7:345-51. [PubMed: 12821405]

17. Chaplan SR, Bach FW, Pogrel JW, Chung JM, Yaksh TL. Quantitative assessment of tactile allodynia in the rat paw. J Neurosci Methods. 1994; 53:55-63. [PubMed: 7990513]

18. Coull JA, Beggs S, Boudreau D, Boivin D, Tsuda M, Inoue K, Gravel C, Salter MW, De Koninck Y. BDNF from microglia causes the shift in neuronal anion gradient underlying neuropathic pain. Nature. 2005; 438:1017-21. [PubMed: 16355225]

19. Coull JA, Boudreau D, Bachand K, Prescott SA, Nault F, Sík A, De Koninck P, De Koninck Y. Trans-synaptic shift in anion gradient in spinal lamina I neurons as a mechanism of neuropathic pain. Nature. 2003; 424:938-42. [PubMed: 12931188]

20. De Groat WC, Lalley PM, Saum WR. Depolarization of dorsal root ganglia in the cat by GABA and related amino acids: antagonism by picrotoxin and bicuculline. Brain Res. 1972; 44:273-7. [PubMed: 4341462] 
21. Delgado-Lezama R, Loeza-Alcocer E, Andrés C, Aguilar J, Guertin PA, Felix R. Extrasynaptic $\mathrm{GABA}_{\mathrm{A}}$ receptors in the brainstem and spinal cord: structure and function. Curr Pharm Des. 2013; 19:4485-97. [PubMed: 23360278]

22. Deschenes M, Feltz P, Lamour Y. A model for an estimate in vivo of the ionic basis of presynaptic inhibition: an intracellular analysis of the GABA-induced depolarization in rat dorsal root ganglia. Brain Res. 1976; 118:486-93. [PubMed: 1009434]

23. Di Lio A, Benke D, Besson M, Desmeules J, Daali Y, Wang ZJ, Edwankar R, Cook JM, Zeilhofer

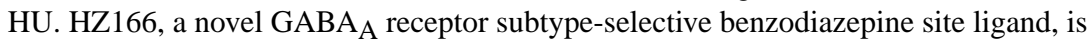
antihyperalgesic in mouse models of inflammatory and neuropathic pain. Neuropharmacology. 2011; 60:626-32. [PubMed: 21145329]

24. Dirig DM, Yaksh TL. Intrathecal baclofen and muscimol, but not midazolam, are antinociceptive using the rat-formalin model. J Pharmacol Exp Ther. 1995; 275:219-27. [PubMed: 7562553]

25. Farrant M, Nusser Z. Variations on an inhibitory theme: Phasic and tonic activation of GABA receptors. Nat Rev Neurosci. 2005; 6:215-29. [PubMed: 15738957]

26. Fritschy JM, Möhler H. GABA ${ }_{A}$-receptor heterogeneity in the adult rat brain: differential regional and cellular distribution of seven major subunits. J Comp Neurol. 1995; 359:154-94. [PubMed: 8557845]

27. Fu KY, Light AR, Maixner W. Relationship between nociceptor activity, peripheral edema, spinal microglial activation and long-term hyperalgesia induced by formalin. Neuroscience. 2000; 101:1127-35. [PubMed: 11113361]

28. Fu KY, Light AR, Maixner W. Long-lasting inflammation and long-term hyperalgesia after subcutaneous formalin injection into the rat hindpaw. J Pain. 2001; 2:2-11. [PubMed: 14622781]

29. Furuyama T, Sato M, Sato K, Araki T, Inagaki S, Takagi H, Tohyama M. Co-expression of glycine receptor beta subunit and $\mathrm{GABA}_{\mathrm{A}}$ receptor gamma subunit mRNA in the rat dorsal root ganglion cells. Brain Res Mol Brain Res. 1992; 12:335-8. [PubMed: 1315905]

30. Godínez-Chaparro B, Barragán-Iglesias P, Castañeda-Corral P, Rocha-González HI, Granados-Soto $\mathrm{V}$. Role of peripheral $5-\mathrm{HT}_{4}, 5-\mathrm{HT}_{6}$, and $5-\mathrm{HT}_{7}$ receptors in development and maintenance of secondary mechanical allodynia and hyperalgesia. Pain. 2011; 152:687-97. [PubMed: 21239110]

31. Hasbargen T, Ahmed MM, Miranpuri G, Li L, Kahle KT, Resnick D, Sun D. Role of NKCC1 and KCC2 in the development of chronic neuropathic pain following spinal cord injury. Ann N Y Acad Sci. 2010; 1198:168-72. [PubMed: 20536931]

32. Hines RM, Davies PA, Moss SJ, Maguire J. Functional regulation of $\mathrm{GABA}_{\mathrm{A}}$ receptors in nervous system pathologies. Curr Opin Neurobiol. 2012; 22:552-8. [PubMed: 22036769]

33. Jiang YL, He XF, Shen YF, Yin XH, DUJY, Liang YI, Fang JQ. Analgesic roles of peripheral intrinsic met-enkephalin and dynorphin A in long-lasting inflammatory pain induced by complete Freund's adjuvant in rats. Exp Ther Med. 2015; 9:2344-48. [PubMed: 26136984]

34. Jolivalt C, Lee C, Ramos M, Calcutt N. Allodynia and hyperalgesia in diabetic rats are mediated by GABA and depletion of spinal potassium-chloride co-transporters. Pain. 2008; 140:48-57. [PubMed: 18755547]

35. Kakinohana O, Hefferan MP, Nakamura S, Kakinohana M, Galik J, Tomori Z, Marsala J, Yaksh TL, Marsala M. Development of GABA-sensitive spasticity and rigidity in rats after transient spinal cord ischemia: a qualitative and quantitative electrophysiological and histopathological study. Neuroscience. 2006; 141:1569-83. [PubMed: 16797137]

36. Knabl J, Witschi R, Hösl K, Reinold H, Zeilhofer UB, Ahmadi S, Brockhaus J, Sergejeva M, Hess A, Brune K, Fritschy JM, Rudolph U, Möhler H, Zeilhofer HU. Reversal of pathological pain through specific spinal $\mathrm{GABA}_{A}$ receptor subtypes. Nature. 2008; 451:330-4. [PubMed: 18202657]

37. Knabl J, Zeilhofer UB, Crestani F, Rudolph U, Zeilhofer HU. Genuine antihyperalgesia by systemic diazepam revealed by experiments in $\mathrm{GABA}_{A}$ receptor point-mutated mice. Pain. 2009; 141:233-8. [PubMed: 19091469]

38. Kullmann DM, Ruiz A, Rusakov DM, Scott R, Semyanov A, Walker MC. Presynaptic, extrasynaptic and axonal $\mathrm{GABA}_{\mathrm{A}}$ receptors in the CNS: where and why? Prog Biophys Mol Biol. 2005; 87:33-46. [PubMed: 15471589]

39. Lee-Kubli C, Calcutt N. Altered rate-dependent depression of the spinal H-reflex as an indicator of spinal disinhibition in models of neuropathic pain. Pain. 2014; 155:250-60. [PubMed: 24103402] 
40. Leem JW, Willis WD, Weller SC, Chung JM. Differential activation and classification of cutaneous afferents in the rat. J Neurophysiol. 1993; 70:2411-24. [PubMed: 8120590]

41. Loeza-Alcozer E, Canto-Bustos M, Aguilar J, González-Ramírez R, Felix R, Delgado-Lezama R. $a_{5} \mathrm{GABA}_{\mathrm{A}}$ receptors mediate primary afferent fiber tonic excitability in the turtle spinal cord. $\mathrm{J}$ Neurophysiol. 2013; 110:2175-84. [PubMed: 23966669]

42. LoPachin RM, Rudy TA, Yaksh TL. An improved method for chronic catheterization of the rat spinal subarachnoid space. Physiol Behav. 1981; 27:559-61. [PubMed: 7335798]

43. Lorenzo LE, Godin AG, Wang F, St-Louis M, Carbonetto S, Wiseman PW, Ribeiro-da-Silva Al, De Koninck Y. Gephyrin clusters are absent from small diameter primary afferent terminals despite the presence of GABA $_{\mathrm{A}}$ receptors. J Neurosci. 2014; 34:8300-17. [PubMed: 24920633]

44. Machelska H, Schopohl JK, Mousa SA, Labuz D, Schäfer M, Stein C. Different mechanisms of intrinsic pain inhibition in early and late inflammation. J Neuroimmunol. 2003; 141:30-9. [PubMed: 12965251]

45. Maddox FN, Valeyev AY, Poth K, Holohean AM, Wood PM, Davidoff RA, Hackman JC, Luetje CW. GABA $A$ receptor subunit mRNA expression in cultured embryonic and adult human dorsal root ganglion neurons. Brain Res Develop. 2004; 149:143-51.

46. McCabe C, Shaw D, Atack JR, Street JL, Wafford KA, Dawson GR, Reynolds DS, Leslie JC. Subtype-selective GABAergic drugs facilitate extinction of mouse operant behavior. Neuropharmacology. 2004; 46:171-8. [PubMed: 14680756]

47. Morales-Aza BM, Chillingworth NL, Payne John A, Donaldson LF. Inflammation alters cation chloride cotransporter expression in sensory neurons. Neurobiol Dis. 2004; 17:62-9. [PubMed: 15350966]

48. Morris ME, Di Costanzo GA, Fox S, Werman R. Depolarizing action of GABA ( $\gamma$-aminobutyric acid) on myelinated fibers of peripheral nerves. Brain Res. 1983; 278:117-26. [PubMed: 6640304]

49. Notter T, Panzanelli P, Pfister S, Mircsof D, Fritschy J. A protocol for concurrent high-quality immunohystochemical and biochemical analyses in adult mouse central nervous system. Eur J Neurosci. 2014; 39:165-75. [PubMed: 24325300]

50. O’Brien DE, Alter BJ, Satomoto M, Morgan CD, Davidson S, Vogt SK, Norman ME, Gereau GB, Demaro JA 3rd, Landreth GE, Golden JP, Gereau RW 4th. ERK2 Alone Drives Inflammatory Pain But Cooperates with ERK1 in Sensory Neuron Survival. J Neurosci. 2015; 35:9491-507. [PubMed: 26109671]

51. Olsen RW, Sieghart W. International Union of Pharmacology. LXX. Subtypes of gammaaminobutyric acid (A) receptors: classification on the basis of subunit composition, pharmacology, and function. Update Pharmacol Rev. 2008; 60:243-60. [PubMed: 18790874]

52. Paul J, Yévenes GE, Benke D, Di Lio A, Ralvenius WT, Witschi R, Scheurer L, Cook JM, Rudolph U, Fritschy JM, Zeilhofer HU. Antihyperalgesia by $\mathrm{a}_{2}-\mathrm{GABA}_{\mathrm{A}}$ receptors occurs via a genuine spinal action and does not involve supraspinal sites. Neuropsychopharmacol. 2014; 39:477-87.

53. Paul J, Zeilhofer HU, Fritschy JM. Selective distribution of $\mathrm{GABA}_{\mathrm{A}}$ receptor subtypes in mouse spinal dorsal horn neurons and primary afferents. J Comp Neurol. 2012; 520:3895-911. [PubMed: 22522945]

54. Persohn E, Malherbe P, Richards JG. In situ hybridization histochemistry reveals a diversity of $\mathrm{GABA}_{\mathrm{A}}$ receptor subunit mRNAs in neurons of the rat spinal cord and dorsal root ganglia. Neuroscience. 1991; 42:497-507. [PubMed: 1654537]

55. Prescott SA, Sejnowski TJ, De Koninck Y. Reduction of anion reversal potential subverts the inhibitory control of firing rate in spinal lamina I neurons: towards a biophysical basis for neuropathic pain. Mol Pain. 2006; 13:32. [PubMed: 17040565]

56. Price T, Cervero F, Gold M, Hammond D, Prescott S. Chloride regulation in the pain pathway. Brain Res Rev. 2009; 60:149-70. [PubMed: 19167425]

57. Quirk K, Blurton P, Fletcher S, Leeson P, Tang F, Mellilo D, Ragan CI, McKernan RM. $[3 \mathrm{H}] \mathrm{L}-655,708$ a novel ligand selective for the benzodiazepine site of $\mathrm{GABA}_{\mathrm{A}}$ receptors which contain the alpha 5 subunit. Neuropharmacology. 1996; 35:1331-5. [PubMed: 9014149]

58. Reese NB, Skinner RD, Mitchell D, Yates C, Barnes CN, Kiser TS, Garcia-Rill E. Restoration of frequency-dependent depression of the H-reflex by passive exercise in spinal rats. Spinal Cord. 2006; 44:28-34. [PubMed: 16044168] 
59. Reichl S, Augustin M, Zahn PK, Pogatzki-Zahn EM. Peripheral and spinal GABAergic regulation of incisional pain in rats. Pain. 2012; 153:129-41. [PubMed: 22054599]

60. Rodgers FC, Zarnowska ED, Laha KT, Engin E, Zeller A, Keist R, Rudolph U, Pearce RA. Etomidate impairs long-term potentiation in vitro by targeting a $a_{5}$-subunit containing $\mathrm{GABA}_{\mathrm{A}}$ receptors on nonpyramidal cells. J Neurosci. 2015; 35:9707-16. [PubMed: 26134653]

61. Rudomin P, Schmidt RF. Presynaptic inhibition in the vertebrate spinal cord revisited. Exp Brain Res. 1999; 129:1-37. [PubMed: 10550500]

62. Semyanov A, Walker MC, Kullmann DM. GABA uptake regulates cortical excitability via cell type-specific tonic inhibition. Nat Neurosci. 2003; 6:484-90. [PubMed: 12679782]

63. Serwanski DR, Miralles CP, Christie SB, Mehta AK, Li X, De Blas AL. Synaptic and nonsynaptic localization of $\mathrm{GABA}_{\mathrm{A}}$ receptors containing the alpha 5 subunit in the rat brain. J Comp Neurol. 2006; 499:458-70. [PubMed: 16998906]

64. Singer E, Placheta P. Reduction of $\left[{ }^{3} \mathrm{H}\right]$-muscimol binding sites in rat dorsal spinal cord after neonatal capsaicin treatment. Brain Res. 1980; 202:484-7. [PubMed: 6159950]

65. Sivilotti L, Woolf CJ. The contribution of $\mathrm{GABA}_{\mathrm{A}}$ and glycine receptors to central sensitization: disinhibition and touch-evoked allodynia in the spinal cord. J Neurophysiol. 1994; 72:169-79. [PubMed: 7965003]

66. Sur C, Quirk K, Dewar D, Atack J, McKernan R. Rat and human hippocampal alpha5 subunitcontaining gamma-aminobutyric acid A receptors have alpha5 beta3 gamma2 pharmacological characteristics. Mol Pharmacol. 1998; 54:928-33. [PubMed: 9804628]

67. Takahashi A, Tokunaga A, Yamanaka H, Mashimo T, Noguchi K, Uchida I. Two types of GABAergic miniature inhibitory postsynaptic currents in mouse substantia gelatinosa neurons. Eur J Pharmacol. 2006; 553:120-8. [PubMed: 17064685]

68. Takazawa T, MacDermott AB. Glycinergic and GABAergic tonic inhibition fine tune inhibitory control in regionally distinct subpopulations of dorsal horn neurons. J Physiol. 2010; 588:2571-87. [PubMed: 20498232]

69. Tokumine J, Kakinohana O, Cizkova D, Smith DW, Marsala M. Changes in spinal GDNF, BDNF, and NT-3 expression after transient spinal cord ischemia in the rat. J Neurosci Res. 2003; 74:55261. [PubMed: 14598299]

70. Willis WD Jr. Dorsal root potentials and dorsal root reflexes: a double-edged sword. Exp Brain Res. 1999; 124:395-421. [PubMed: 10090653]

71. Xiao HS, Huang QH, Zhang FX, Bao L, Lu YJ, Guo C, Yang L, Huang WJ, Fu G, Xu SH, Cheng XP, Yan Q, Zhu ZD, Zhang X, Chen Z, Han ZG, Zhang H. Identification of gene expression profile of dorsal root ganglion in the rat peripheral axotomy model of neuropathic pain. PNAS. 2002; 99:8360-5. [PubMed: 12060780]

72. Yamamoto T, Yaksh TL. Effects of intrathecal strychnine and bicuculline on nerve compressioninduced thermal hyperalgesia and selective antagonism by MK-801. Pain. 1993; 54:79-84. [PubMed: 8378105]

73. Yang L, Zhang FX, Huang F, Lu YJ, Li GD, Bao L, Xiao HS, Zhang X. Peripheral nerve injury induces trans-synaptic modification of channels, receptors and signal pathways in rat dorsal spinal cord. Eur J Neurosci. 2004; 19:871-83. [PubMed: 15009134]

74. Zeilhofer HU, Benke D, Yevenes GE. Chronic pain states: Pharmacological strategies to restore diminished inhibitory spinal pain control. Annu Rev Pharmacol Toxicol. 2012; 52:111-33. [PubMed: 21854227]

75. Zhu Y, Dua S, Gold MS. Inflammation-induced shift in spinal GABA $A_{A}$ signaling is associated with a tyrosine - kinase dependent increase in $\mathrm{GABA}_{\mathrm{A}}$ current density in nociceptive afferents. $\mathbf{J}$ Neurophysiol. 2012; 108:2581-93. [PubMed: 22914654]

76. Zimmermann M. Ethical guidelines for investigations of experimental pain in conscious animals. Pain. 1983; 16:109-10. [PubMed: 6877845] 


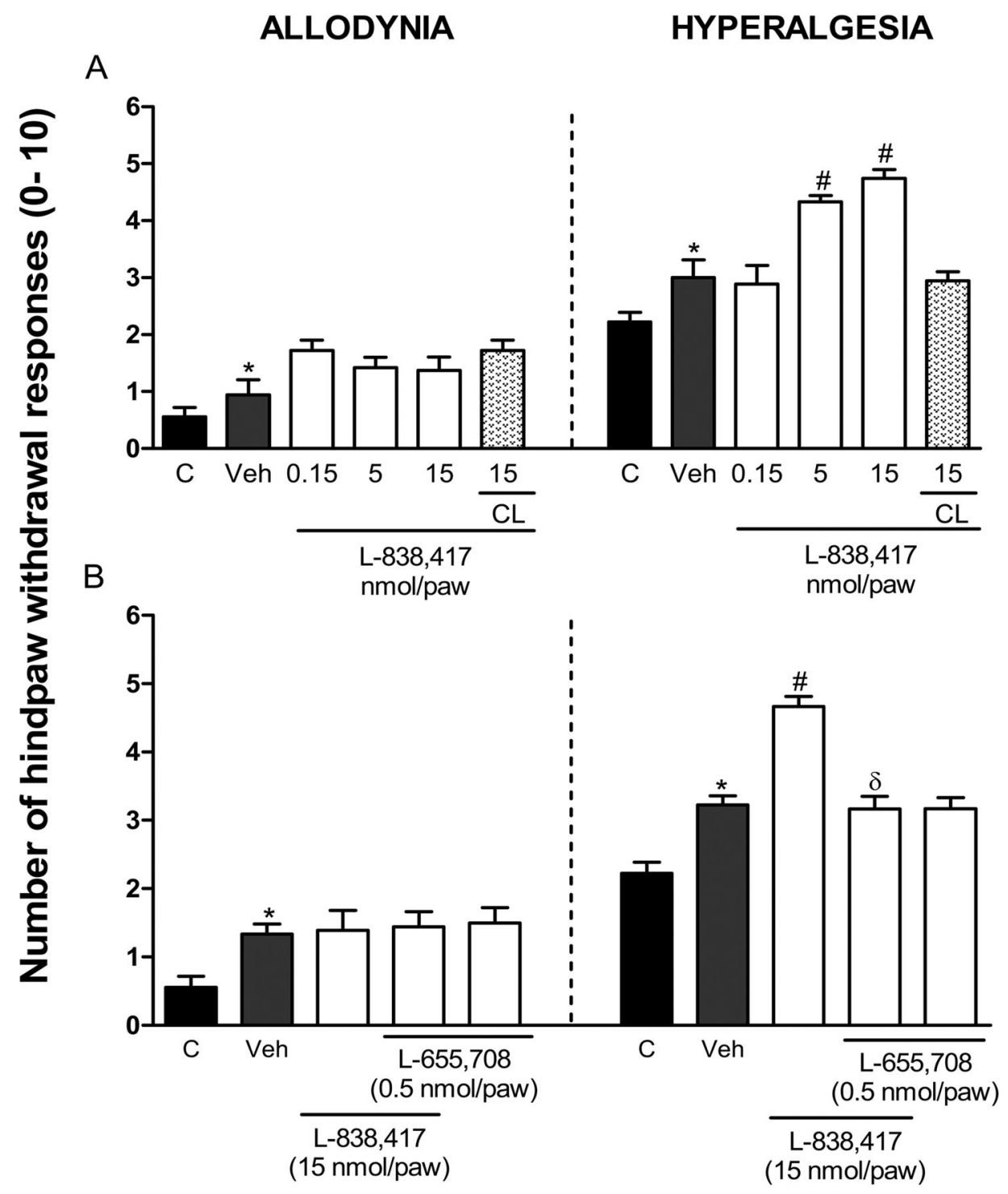

Figure 1.

Peripheral $a_{5}-\mathrm{GABA}_{\mathrm{A}}$ receptors are involved in the development of formalin-induced longlasting secondary hyperalgesia. Effect of pre-treatment (10 min) with the $\mathrm{a}_{2^{-}}, \mathrm{a}_{3^{-}}$and $\mathrm{a}_{5^{-}}$ $\mathrm{GABA}_{\mathrm{A}}$ receptors partial agonist L-838,417 (panel A) and effect of L-655,708 (0.5 nmol/ paw) on the pronociceptive effect produced by L-838,417 (15 nmol/paw) in $0.5 \%$ formalininduced mechanical secondary allodynia and hyperalgesia (panel B). Data are expressed as the mean $(n=6) \pm$ SEM of paw withdrawal ipsilateral response to the applications of von Frey filaments $(10$ and $250 \mathrm{mN})$ to the plantar surface of rat paws before (control, C) and after formalin plus vehicle (Veh) or drug injection. ${ }^{*} \mathrm{P}<0.05$ versus control group, ${ }^{*} \mathrm{P}<0.05$ versus Veh group, and ${ }^{\&} \mathrm{P}<0.05$ versus $\mathrm{L}-838,417$ group, by one-way ANOVA followed by the Student-Newman-Keuls post-hoc test. 

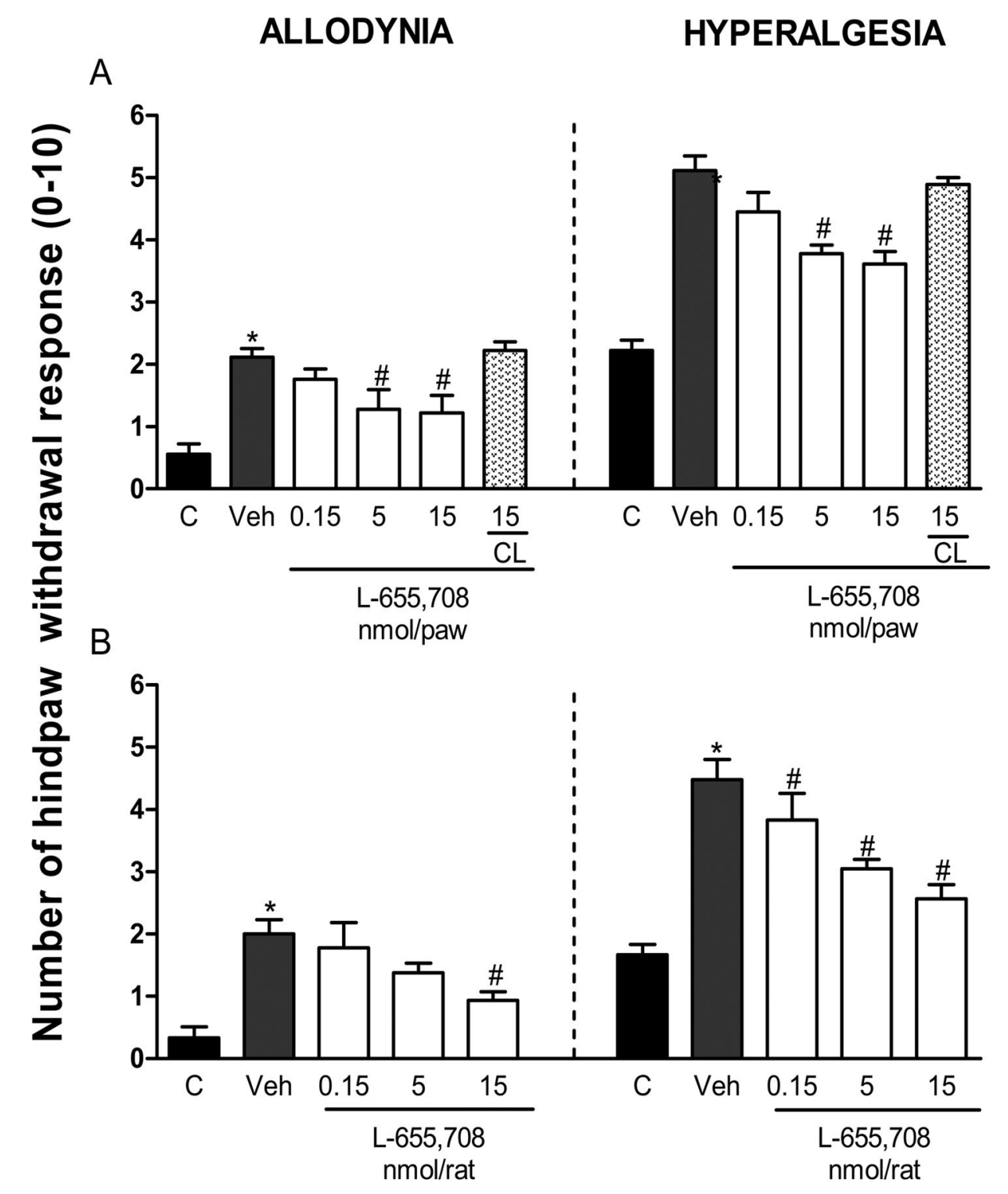

Figure 2.

Local peripheral and spinal $\mathrm{a}_{5}-\mathrm{GABA}_{\mathrm{A}}$ receptors are involved in the development of formalin-induced long-lasting secondary allodynia and hyperalgesia. Effect of local peripheral (panel A) and intrathecal (panel B) pre-treatment (10 min) with the selective $a_{5^{-}}$ $\mathrm{GABA}_{\mathrm{A}}$ receptors antagonist L-655,708 $(0.15-15 \mathrm{nmol} / \mathrm{rat})$ on $1 \%$ formalin-induced mechanical secondary allodynia and hyperalgesia. Data are expressed as the mean $(n=6) \pm$ SEM of paw withdrawal ipsilateral response to the application of von Frey filaments (10 and $250 \mathrm{mN}$ ) to the plantar surface of rat paws before (control, C) and after formalin plus vehicle (Veh) or drug injection. ${ }^{*} \mathrm{P}<0.05$ versus $\mathrm{C}$ group, ${ }^{\#} \mathrm{P}<0.05$ versus Veh group, by one-way ANOVA followed by the Student-Newman-Keuls post-hoc test. CL: Contralateral. 


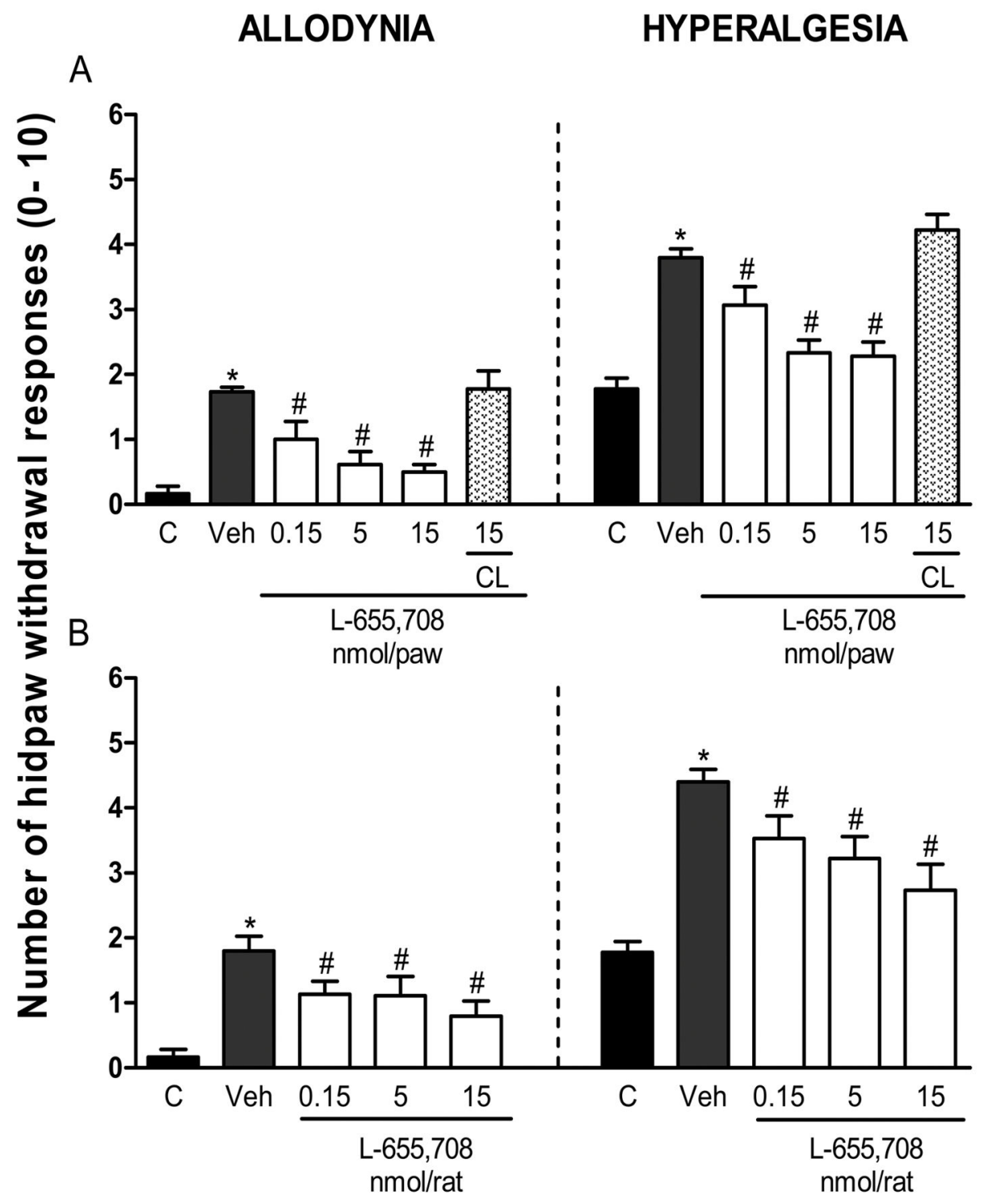

Figure 3.

Peripheral and spinal $\mathrm{a}_{5}-\mathrm{GABA}_{\mathrm{A}}$ receptors are involved in the maintenance of formalininduced long-lasting secondary allodynia and hyperalgesia. Effect of peripheral (panel A) and intrathecal (panel B) post-treatment (6 days after $1 \%$ formalin injection) with the selective $a_{5}-\mathrm{GABA}_{\mathrm{A}}$ receptors antagonist L-655,708 (0.15-15 nmol/rat) on $1 \%$ formalininduced mechanical secondary allodynia and hyperalgesia. Data are expressed as the mean $(n=6) \pm$ SEM of paw withdrawal ipsilateral response to the applications of von Frey filaments $(10$ and $250 \mathrm{mN}$ ) on the plantar surface of rat paws before (control, C) and after formalin plus vehicle (Veh) or drug injection. ${ }^{*} \mathrm{P}<0.05$ versus $\mathrm{C}$ group, ${ }^{\#} \mathrm{P}<0.05$ versus Veh group, by one-way ANOVA followed by the Student-Newman-Keuls post-hoc test. CL: Contralateral. 
A
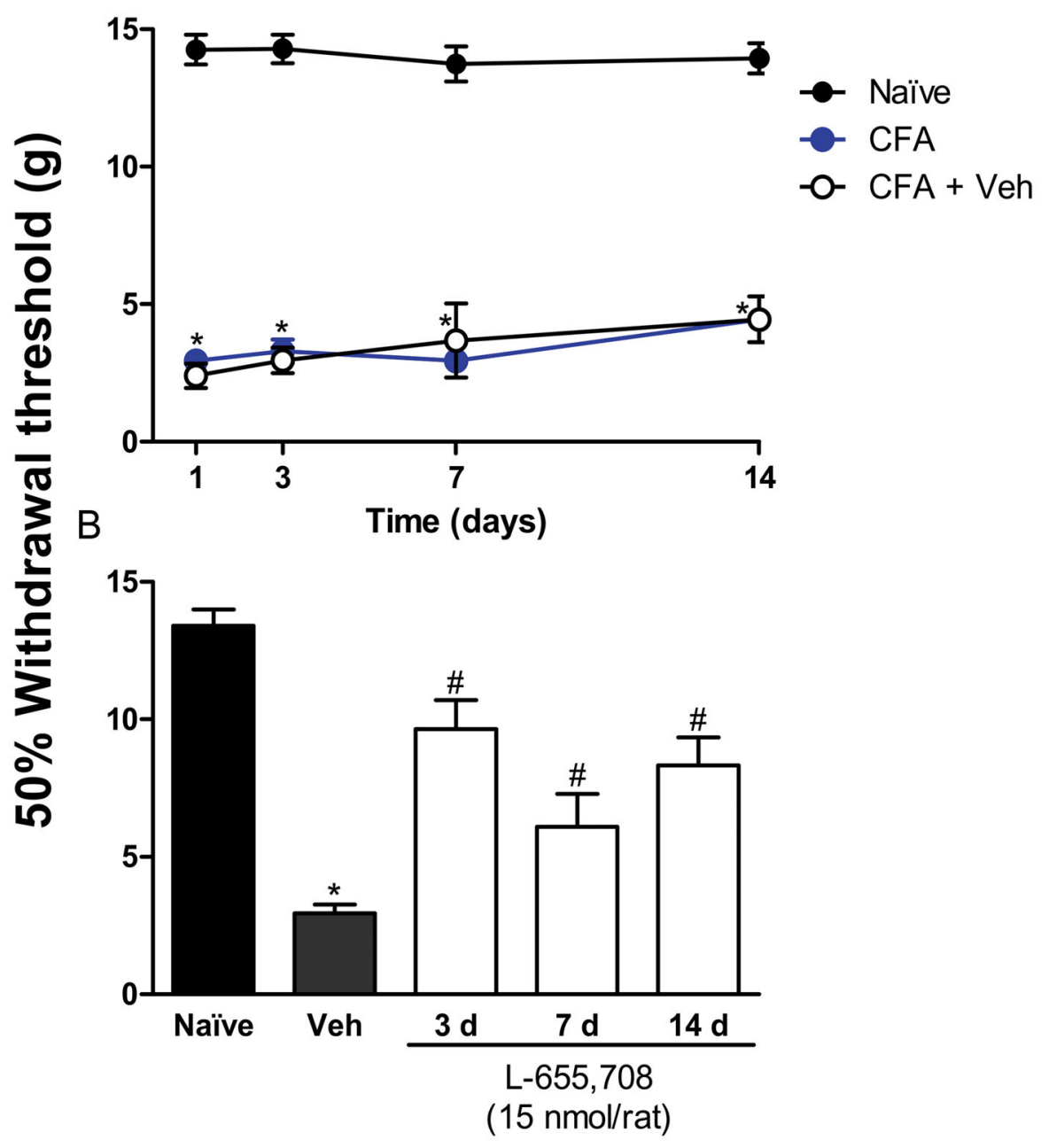

Figure 4.

$\mathrm{a}_{5}-\mathrm{GABA}_{\mathrm{A}}$ receptors are involved in the development and maintenance of CFA-induced tactile allodynia. Time-course of the 50\% withdrawal threshold in naïve and CFA-treated rats (panel A). Effect of intrathecal administration of the selective $a_{5}-\mathrm{GABA}_{\mathrm{A}}$ receptors antagonist L-655,708 on CFA-induced tactile allodynia (panel B). Withdrawal threshold was assessed $1 \mathrm{~h}$ post-drug administration at 3,7 and 14 days after CFA injection. Data are presented as the $50 \%$ withdrawal threshold for 6 animals \pm SEM. $* \mathrm{P}<0.05$ versus sham group, ${ }^{\#} \mathrm{P}<0.05$ versus Veh group, by one- or two-way ANOVA followed by the StudentNewman-Keuls post-hoc test. CFA: Complete Freund's adjuvant); Veh: Vehicle. 

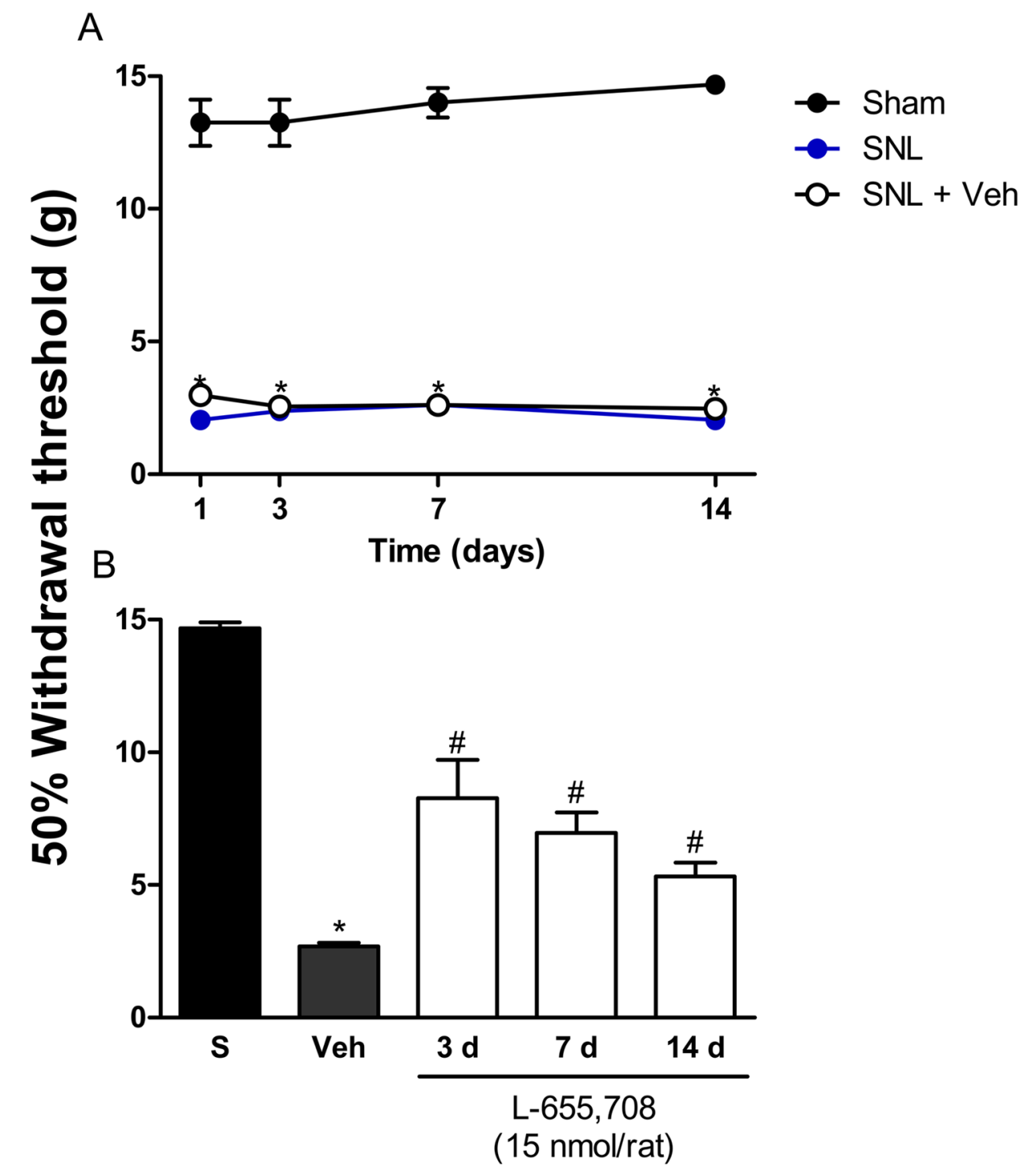

Figure 5.

$a_{5}-G_{A B A}$ receptors are involved in the development and maintenance of neuropathic pain in rats. Time-course of the $50 \%$ withdrawal threshold in sham and spinal nerve ligated rats (panel A). Effect of intrathecal administration of the selective $a_{5}-G_{A B A}$ receptors antagonist L-655,708 on spinal nerve ligated-induced tactile allodynia (panel B). Withdrawal threshold was assessed $1 \mathrm{~h}$ post-drug administration at 3, 7 and 14 days after spinal nerve ligation. Data are presented as the mean withdrawal threshold for 6 animals \pm SEM. $* \mathrm{P}<0.05$ versus sham group, ${ }^{*} \mathrm{P}<0.05$ versus Veh group, by one- or two-way ANOVA followed by the Student-Newman-Keuls post-hoc test. SNL: L5/L6 spinal nerve injury (SNL); S: Sham (S); Veh: Vehicle. 
A

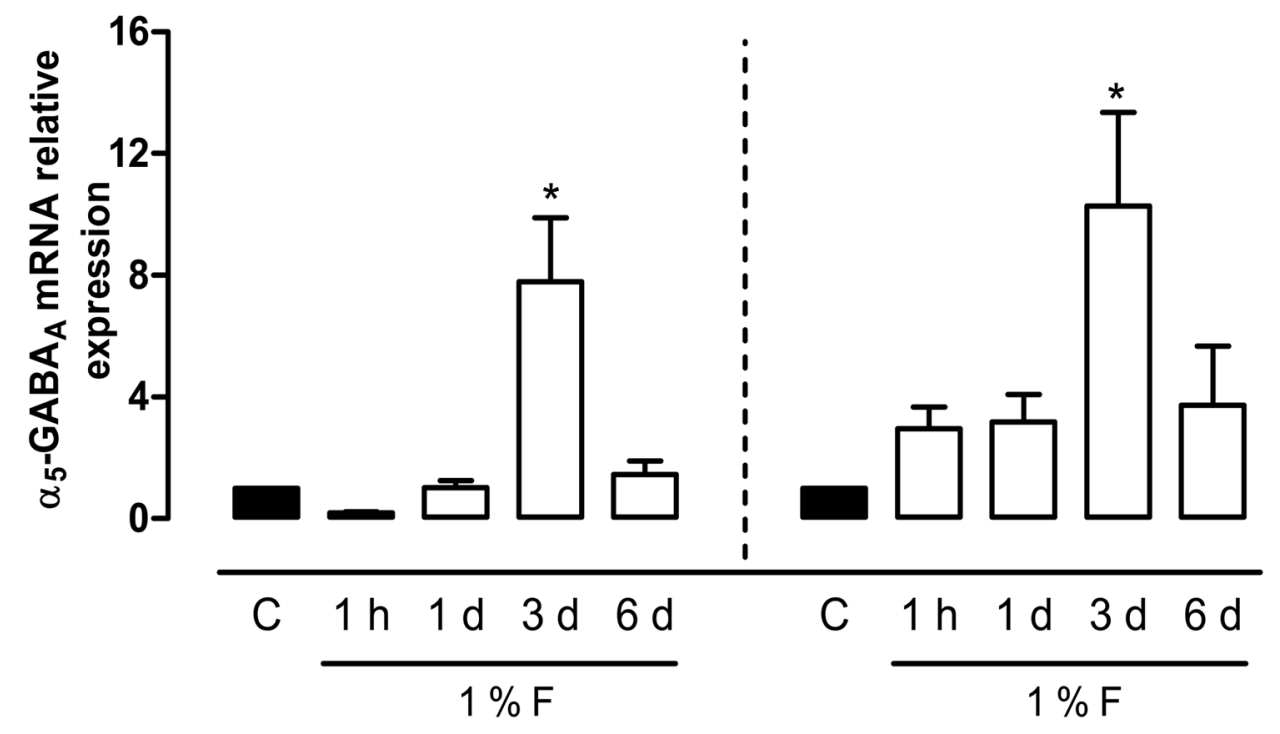

Figure 6.

Expression of $a_{5}-\mathrm{GABA}_{\mathrm{A}}$ receptors $\mathrm{mRNA}$ is modulated by formalin injection. qPCR data for mRNA relative expression of the $a_{5}-\mathrm{GABA}_{\mathrm{A}}$ receptors in the dorsal spinal cord and L4L6 DRGs at $1 \mathrm{~h}$ and 1, 3 and 6 days after $1 \%$ formalin injection. Data are expressed as mean \pm SEM of 3 independent animals. ${ }^{*} \mathrm{P}<0.05$ versus control $(\mathrm{C})$, by one-way ANOVA followed by the Student-Newman-Keuls post-hoc test. 

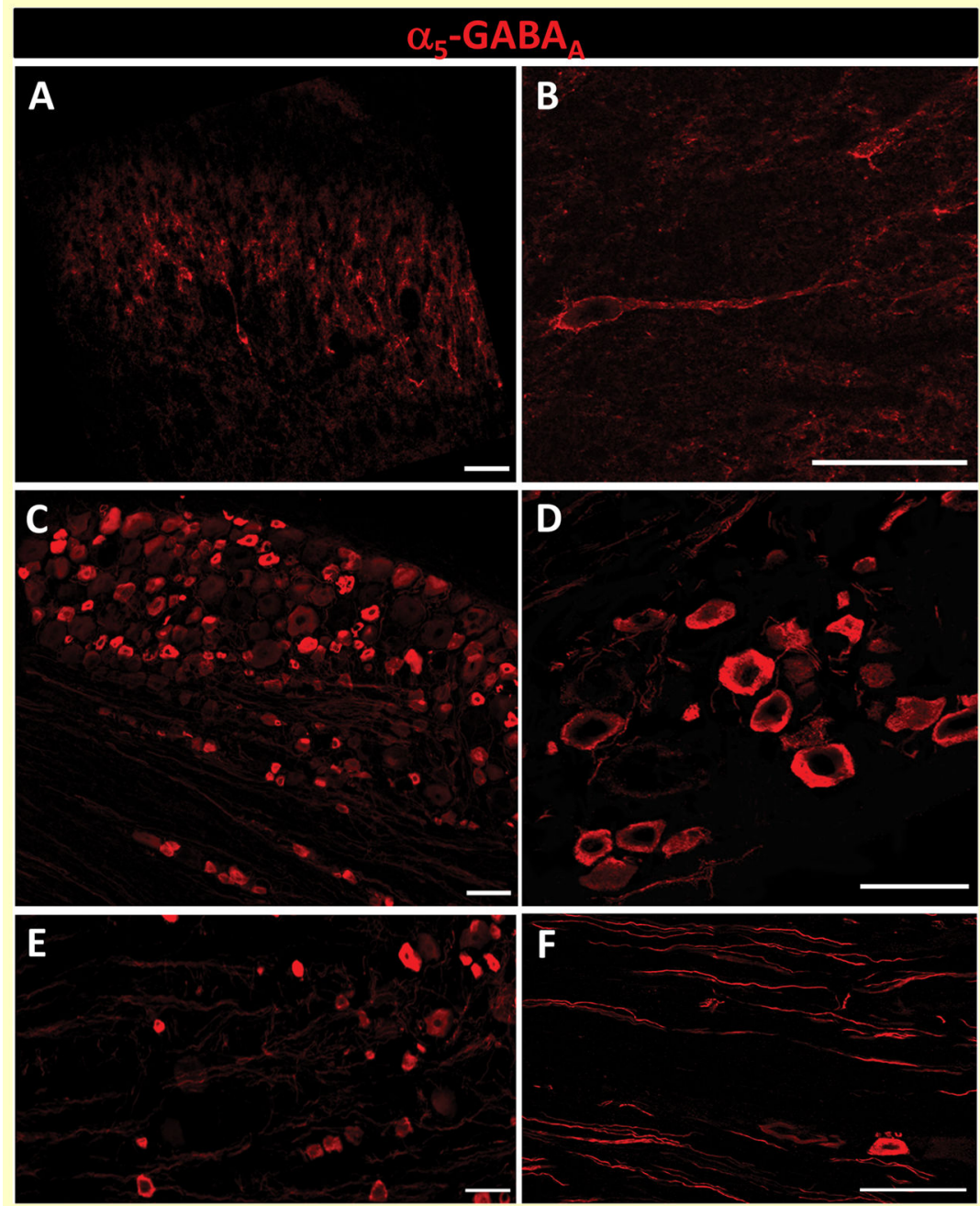

Figure 7.

$\mathrm{a}_{5}-\mathrm{GABA}_{\mathrm{A}}$ receptors are expressed in the dorsal horn and DRG. Representative images of the transverse section of the spinal dorsal horn (panels A and B), sagittal sections of DRG (panels $\mathrm{C}$ and $\mathrm{D}$ ) and primary afferent fibers (panels $\mathrm{E}$ and $\mathrm{F}$ ) showing the distribution of $\mathrm{a}_{5^{-}}$ $\mathrm{GABA}_{\mathrm{A}}$ receptors immunoreactivity (scale bar: $50 \mu \mathrm{m}$ ). 
A
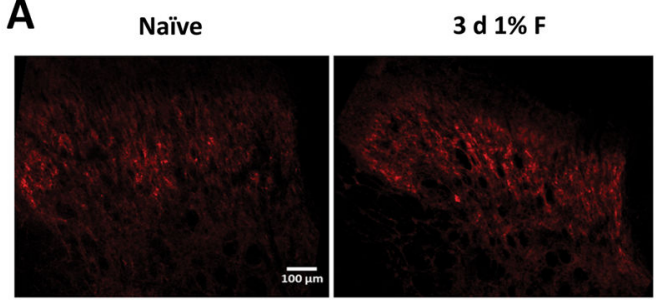

C
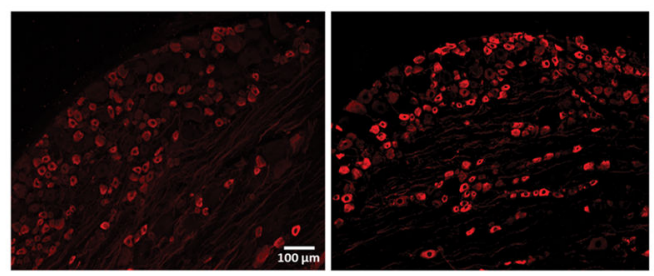
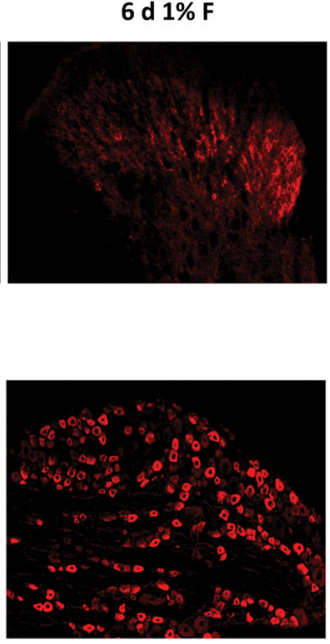

B

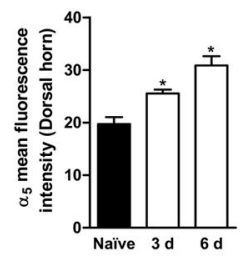

D

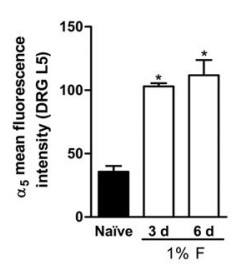

Figure 8.

Formalin injection modulates $\mathrm{a}_{5}-\mathrm{GABA}_{\mathrm{A}}$ receptors immunoreactivity. Representative staining of $\mathrm{a}_{5}-\mathrm{GABA}_{\mathrm{A}}$ on the dorsal spinal cord (panel A) and L5 DRG (panel C) from naïve (left) and formalin-treated rats at 3 (middle) and 6 days (right) after injection.

Quantification of immunofluorescence signals for $\mathrm{a}_{5}-\mathrm{GABA}_{\mathrm{A}}$ receptors in naïve and 3 and 6 days after $1 \%$ formalin injection (5 sections from 3 independent animals) in the dorsal spinal cord (panel B) and L5 DRG (panel D). * $\mathrm{P}<0.05$ versus naïve, by one-way ANOVA followed by the Student-Newman-Keuls post-hoc test. 

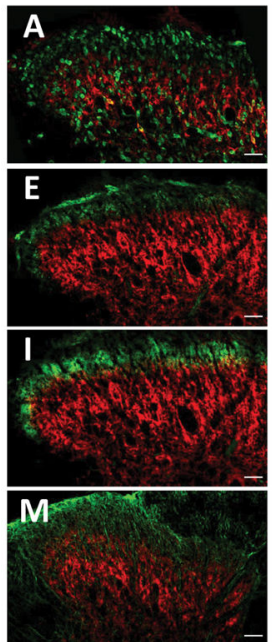

Q

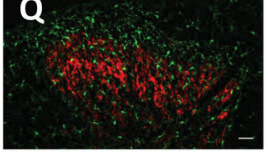

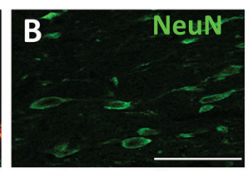

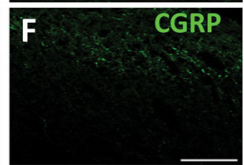

J.

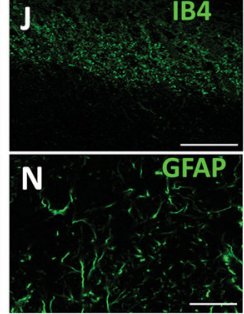

$\mathbf{R}$

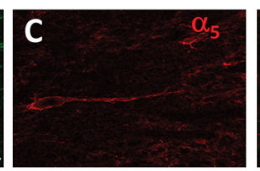

G
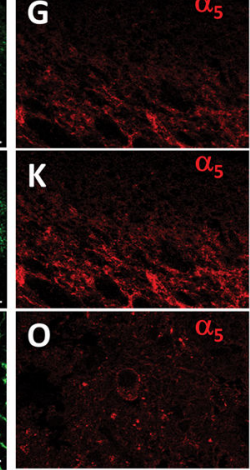

S
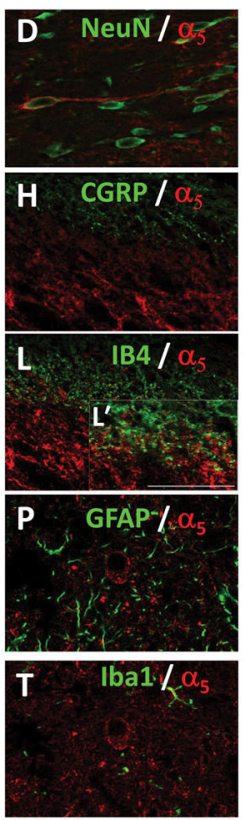

Figure 9.

Distribution of $\mathrm{a}_{5}-\mathrm{GABA}_{\mathrm{A}}$ receptors in dorsal horn spinal cord. Panels A, B, C and D: $\mathrm{NeuN}$ (green), $a_{5}-\mathrm{GABA}_{\mathrm{A}}$ receptors (red) and its co-expression (yellow) in dorsal horn neurons. Of note, $a_{5}-\mathrm{GABA}_{\mathrm{A}}$ receptors immunoreactivity is present on the membrane and along the axon. Panels H E, F, G and: CGRP (green) and $\mathrm{a}_{5}-\mathrm{GABA}_{\mathrm{A}}$ receptors (red) immunoreactivity is distributed in two different populations of fibers in the dorsal horn. I, J, $\mathrm{K}, \mathrm{L}$ and L': IB4 (green), $\mathrm{a}_{5}-\mathrm{GABA}_{\mathrm{A}}$ receptors (red) and their co-expression (yellow) in non-peptidergic fibers. Panels M, N, O and P: GFAP (green) is expressed in astrocytes throughout the spinal cord and $\mathrm{a}_{5}-\mathrm{GABA}_{\mathrm{A}}$ receptors (red) are localized in specific primary afferents fibers and second order neurons. Panels Q, R, S and T: Iba1 (green) is expressed in microglia throughout the spinal cord and $\mathrm{a}_{5}-\mathrm{GABA}_{\mathrm{A}}$ receptors (red) are localized in specific primary afferents fibers and second order neurons. Some $\mathrm{a}_{5}-\mathrm{GABA}_{\mathrm{A}}$ receptors immunoreactive fibers are in close contact with Iba1 microglia (panels $\mathrm{Q}$ and $\mathrm{T}$ ). Scale bar: $50 \mu \mathrm{m}$. Confocal images: one optical section $0.2 \mu \mathrm{M}$. 

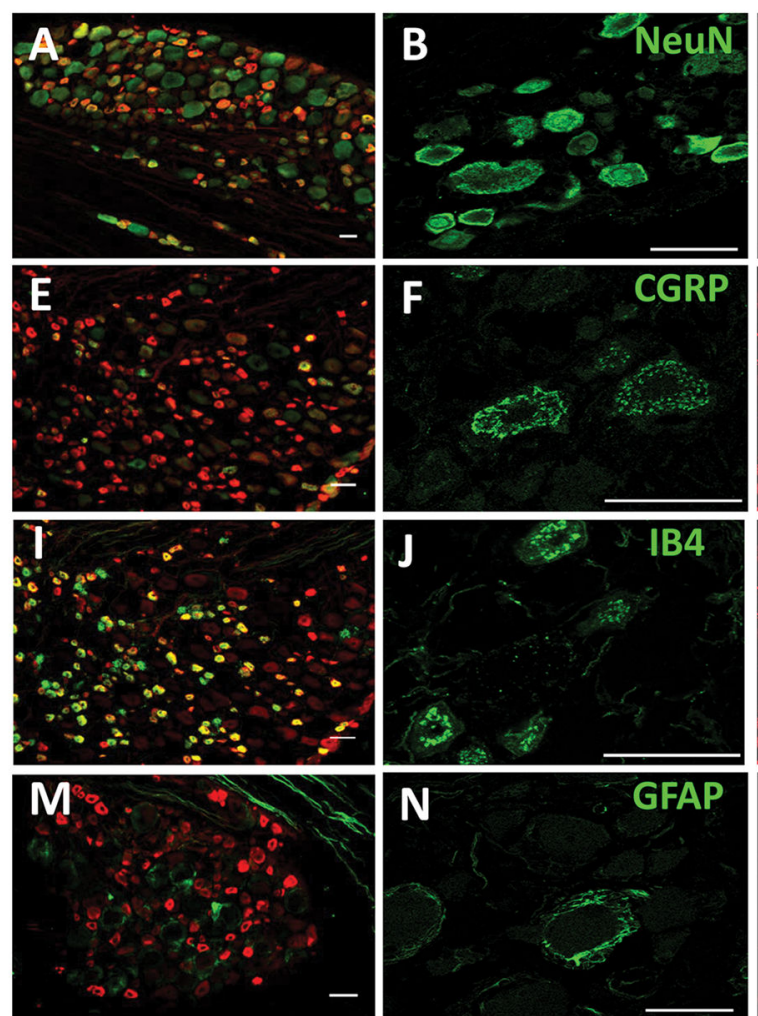
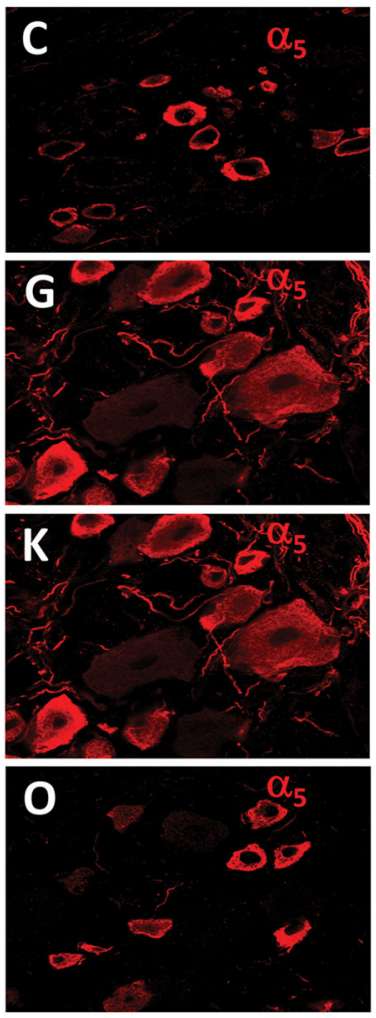
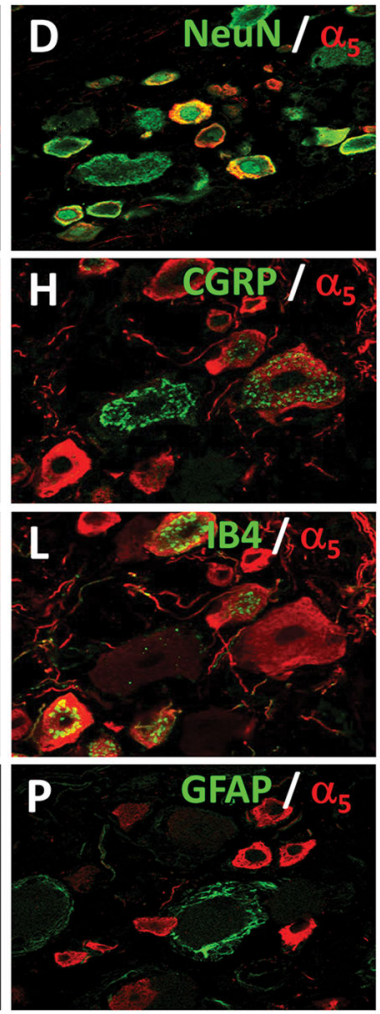

Figure 10.

Distribution of $\mathrm{a}_{5}-\mathrm{GABA}_{\mathrm{A}}$ receptors in DRG. Panels A, B, C and D: NeuN (green), $a_{5^{-}}$ $\mathrm{GABA}_{\mathrm{A}}$ receptors (red) and their co-localization (yellow) in small-to medium size neurons. Panels E, F, G and H: CGRP (green) and $\mathrm{a}_{5}-\mathrm{GABA}_{\mathrm{A}}$ receptors (red) immunoreactivity are distributed in small to medium size neurons, some neurons are immuoreactive for both. Panels I, J, K and L: IB4 (green), $\mathrm{a}_{5}-\mathrm{GABA}_{\mathrm{A}}$ receptors (red) and their co-expression (yellow) in non-peptidergic small to medium size neurons. Panels M, N, O and P: GFAP (green) is expressed in satellite glial cells and $\mathrm{a}_{5}-\mathrm{GABA}_{\mathrm{A}}$ receptors (red) are localized in specific non-peptidergic small to medium size neurons. Scale bar: $50 \mu \mathrm{m}$. Confocal images: one optical section $0.2 \mu \mathrm{M}$. 


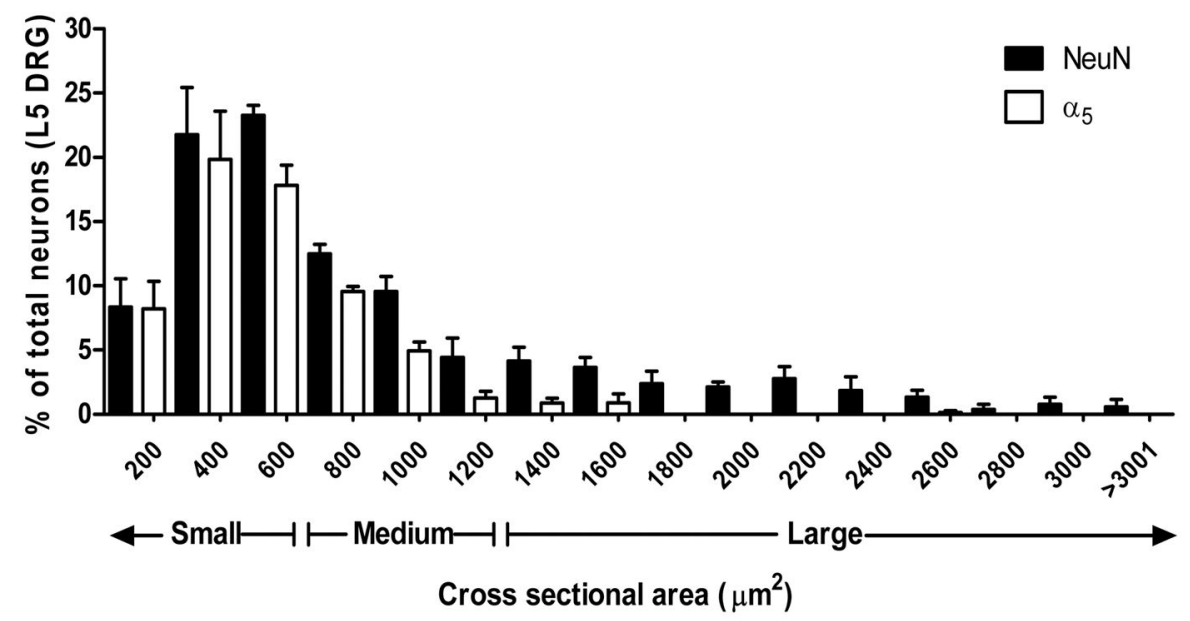

Figure 11.

Size distribution data of $\mathrm{a}_{5}-\mathrm{GABA}_{\mathrm{A}}$ receptors + and NeuN + neurons in L5 DRG. Data were obtain from 5 sections of 3 naïve animas using imageJ software to manually measure crosssectional area of neurons in $12 \mu \mathrm{m}$-thick sections. Data are plotted as \% of total number of neurons. 
A

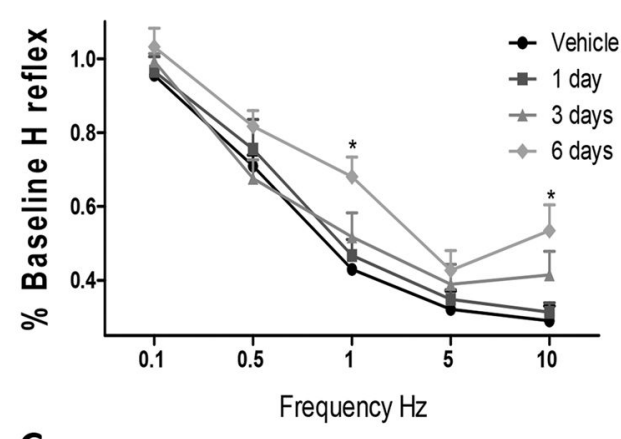

C

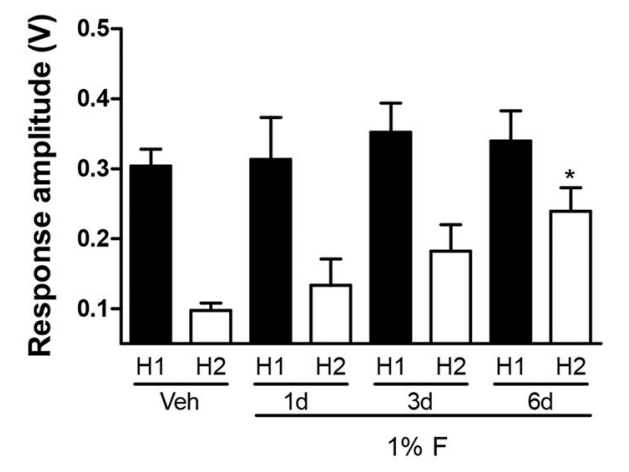

B

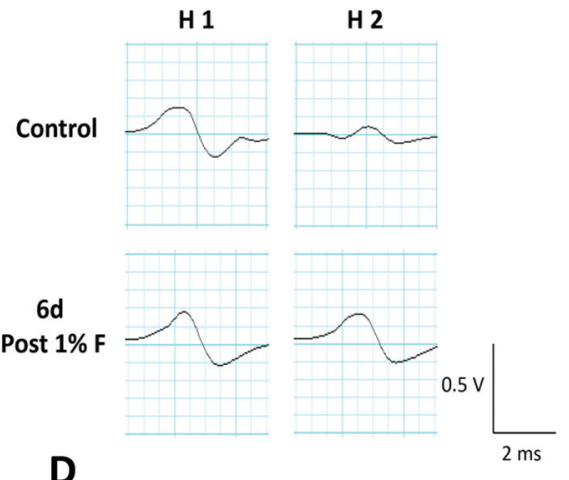

D

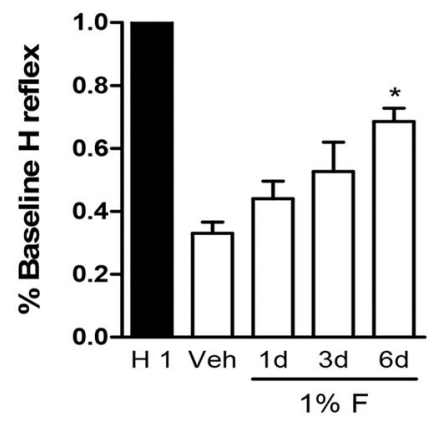

Figure 12.

Formalin-induced impairment of the rate dependent depression (RDD) of the Hofmann reflex. Panel A: \% Baseline of the Hofmann reflex showing the presence (control rats) and loss $(1,3$ and 6 days after $1 \% \mathrm{~F})$ of RDD induced by the increment of stimulation frequency $(0.1-10 \mathrm{~Hz})$. Note the significant impairment of RDD at $1 \mathrm{~Hz}$ measured 6 days after formalin treatment, as compared to control rats. Panel B: Representative recording in one control rat (top, control) and 6 days post-formalin injection (bottom, 6 days, post $1 \% \mathrm{~F}$ ) comparing the first stimulus (H1) versus the second stimulus $(\mathrm{H} 2)$ at a $1 \mathrm{~Hz}$. Note that the amplitude of $\mathrm{H} 2$ was not different from that of $\mathrm{H} 1$ in the formalin-treated rats. Panel $\mathrm{C}$ : Response amplitude comparing $(\mathrm{H} 1)$ versus $(\mathrm{H} 2)$ in rats treated with vehicle or 1, 3, 6 days after formalin injection $(1 \% \mathrm{~F})$. Note that $\mathrm{H} 1$ does not change with time or formalin treatment while $\mathrm{H} 2$ is restored in a time-dependent manner. Panel D: Time-dependent impairment of the RDD of the Hofmann reflex ( $\mathrm{H}$ reflex) in $\mathrm{H} 2$ compared to \% Baseline $\mathrm{H}$ reflex normalized to $\mathrm{H} 1$ in rats treated with vehicle or 1, 3, 6 days after formalin injection. Data are expressed as the mean $(\mathrm{n}=7$ rats $) \pm$ SEM. $* \mathrm{P}<0.05$ versus vehicle (Veh), by oneway ANOVA followed by the Student Newman Keuls post-hoc test. 
H 1
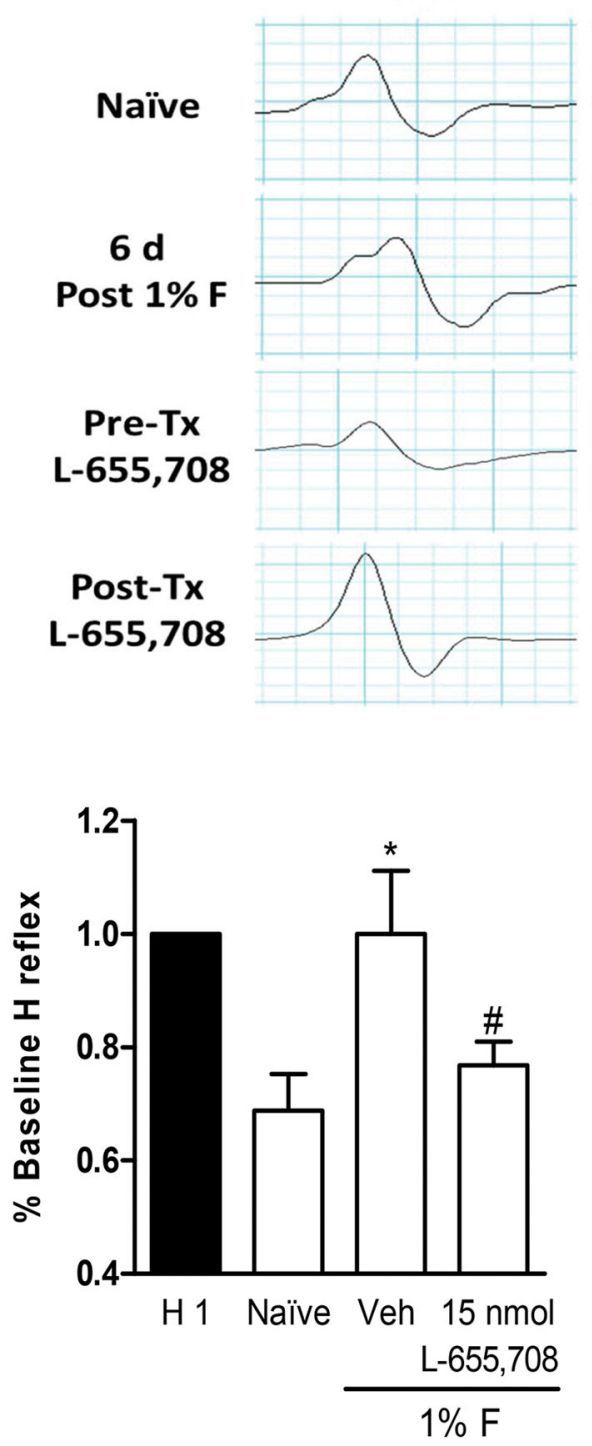

H 2
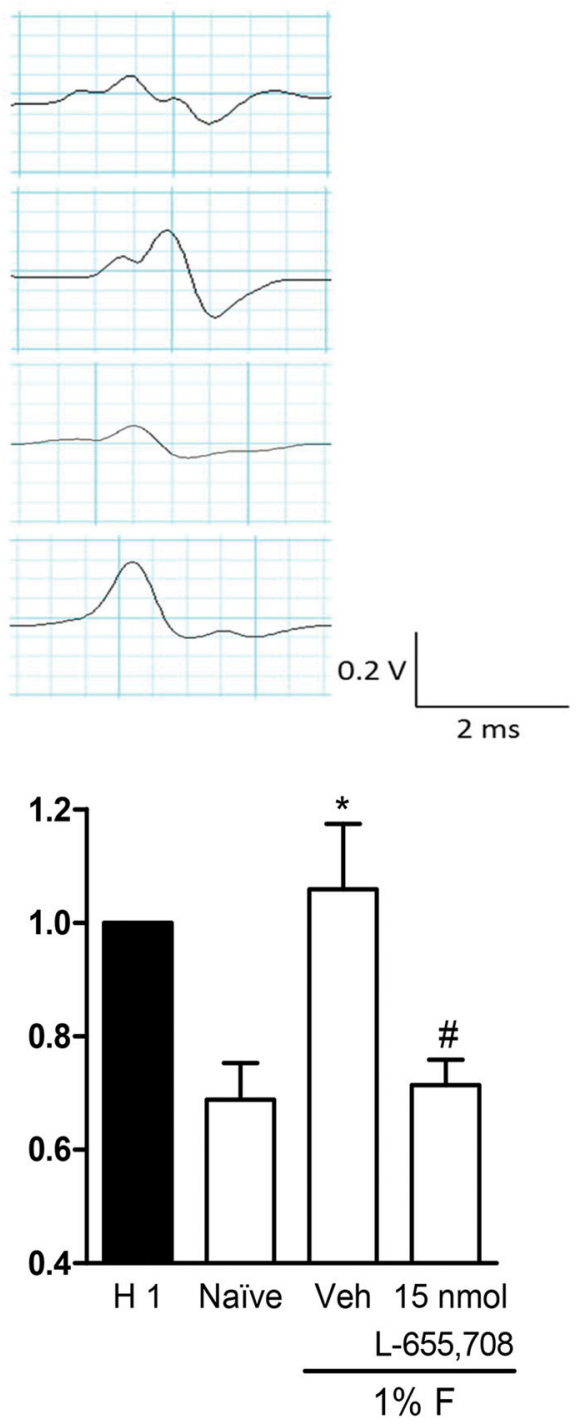

Figure 13.

L-655,708 restores RDD of the Hofmann reflex in formalin-treated rats. Panel A:

Representative recordings of RDD of the Hofmann reflex in naïve (first row), 6 days postformalin injection (second row), pre-treated with L-655,708 $+1 \%$ formalin (third row) and post-treated with L-655,708 + 1\% formalin (last row) rats. Panel B: Intrathecal L-655,708, delivered as a pre-treatment (10 min), significantly prevented the loss of RDD of the Hofmann reflex 6 days after $1 \%$ formalin administration. Panel C: Intrathecal L-655708, delivered as a post-treatment, reversed the loss of RDD of the Hofmann reflex 6 days after $1 \%$ formalin administration. Data are expressed as the rate dependent depression of the Hofmann reflex (\% baseline $\mathrm{H}$ reflex) comparing the $\mathrm{H} 1$ versus $\mathrm{H} 2$ at $1 \mathrm{~Hz}$ for 5 animals per group * $\mathrm{P}<0.05$ versus naïve, ${ }^{\#} \mathrm{P}<0.05$ versuss Vehicle (Veh), by one-way ANOVA followed by the Student Newman Keuls post-hoc test. 